\title{
Coastal hypoxia and sediment biogeochemistry
}

\author{
J. J. Middelburg ${ }^{1,2}$ and L. A. Levin ${ }^{3}$ \\ ${ }^{1}$ Netherlands Institute of Ecology (NIOO-KNAW), Korringaweg 7, 4401 NT Yerseke, The Netherlands \\ ${ }^{2}$ Faculty of Geosciences, Utrecht University, P.O. Box 80021, 3508 TA Utrecht, The Netherlands \\ ${ }^{3}$ Integrative Oceanography Division, Scripps Inst. of Oceanography, 9500 Gilman Drive, La Jolla, CA 92093-0218, USA
}

Received: 25 March 2009 - Published in Biogeosciences Discuss.: 6 April 2009

Revised: 29 June 2009 - Accepted: 4 July 2009 - Published: 28 July 2009

\begin{abstract}
The intensity, duration and frequency of coastal hypoxia (oxygen concentration $<63 \mu \mathrm{M}$ ) are increasing due to human alteration of coastal ecosystems and changes in oceanographic conditions due to global warming. Here we provide a concise review of the consequences of coastal hypoxia for sediment biogeochemistry. Changes in bottomwater oxygen levels have consequences for early diagenetic pathways (more anaerobic at expense of aerobic pathways), the efficiency of re-oxidation of reduced metabolites and the nature, direction and magnitude of sediment-water exchange fluxes. Hypoxia may also lead to more organic matter accumulation and burial and the organic matter eventually buried is also of higher quality, i.e. less degraded. Bottom-water oxygen levels also affect the organisms involved in organic matter processing with the contribution of metazoans decreasing as oxygen levels drop. Hypoxia has a significant effect on benthic animals with the consequences that ecosystem functions related to macrofauna such as bio-irrigation and bioturbation are significantly affected by hypoxia as well. Since many microbes and microbial-mediated biogeochemical processes depend on animal-induced transport processes (e.g. re-oxidation of particulate reduced sulphur and denitrification), there are indirect hypoxia effects on biogeochemistry via the benthos. Severe long-lasting hypoxia and anoxia may result in the accumulation of reduced compounds in sediments and elimination of macrobenthic communities with the consequences that biogeochemical properties during trajectories of decreasing and increasing oxygen may be different (hysteresis) with consequences for coastal ecosystem dynamics.
\end{abstract}

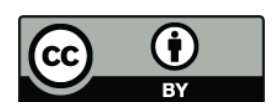

Correspondence to: J. J. Middelburg (j.middelburg@ nioo.knaw.nl)

\section{Introduction}

Dissolved oxygen concentrations in natural water bodies are governed by the delicate balance between the processes of oxygen supply (mainly regulated by physical transport) and removal (primarily through biological consumption). The occurrence of coastal hypoxia can be natural, human influenced, or result from the interactions of natural and anthropogenically-induced processes. Naturally occurring hypoxia is found in bottom waters of silled basins and fjords with restricted circulation (e.g. Black Sea, Cariaco Basin, Kau Bay, Anderson and Devol, 1987; Middelburg et al., 1991), as a result of natural intrusions or upwelling of subsurface oxygen-depleted waters on shelf systems (northern Chile, Morales et al., 1999; northeast Pacific, Grantham et al., 2004; Costa Rica, Thamdrup et al., 1996; Namibian shelf, Monteiro et al., 2006, 2008; Lavik et al., 2009; Indian shelf, Naqvi et al., 2000), or in coastal embayments such as estuaries from the heterotrophic status sustained by the delivery of terrestrial and riverine organic matter (Heip et al., 1995). Human influences on coastal hypoxia are multiple and can operate on local and regional scales (e.g. cultural eutrophication, river runoff) as well as the global scale (e.g. warming). Global warming will lead to reduced oxygen solubility and degassing of oxygen, increased stratification and changes in wind patterns affecting transport and mixing of oxygen. Modifications in hydrology may influence the delivery of nutrients and organic matter from land to coastal systems and thus the consumption of oxygen in coastal systems (Rabalais et al., 2004; Turner et al., 2008). Hydrological changes can also result in enhanced stratification due to either elevated evapotranspiration in arid zones or freshwater lenses resulting from excessive rain or runoff from land. These natural and human-influenced processes influencing the oxygen balance in coastal waters interact and together govern dissolved oxygen dynamics. 
There is accumulating evidence and growing concern that low oxygen (i.e. hypoxic) conditions are proliferating in marine coastal environments worldwide (Diaz, 2001; Gray et al., 2002; Rabalais et al., 2001a, b; Diaz and Rosenberg, 2008). Hypoxia can have direct and indirect effects on the functioning and survival of organisms. The vulnerability to low oxygen varies widely across marine organisms. Changes in organism behaviour and functioning are generally observed at higher dissolved oxygen levels than lethal oxygen thresholds (Diaz and Rosenberg, 1995; Gray et al., 2002; Vaquer-Sunyer and Duarte, 2008). Moreover, anoxic conditions with or without sulphide may have different consequences because of the toxicity of sulphides for many organisms, in particular metazoans (Bagarinao, 1992). Another important factor governing the sensitivity of organisms to hypoxia is the duration of hypoxic conditions, as short-lived events can be survived or avoided by migration (Levin et al., 2009a). It is the combination of sensitivity to oxygen levels and the duration and intensity of hypoxia that governs the survival and functioning of organisms under conditions of coastal hypoxia. Oxygen thresholds should therefore be considered in a dynamic context.

Coastal hypoxia may be an incidental or episodic event (e.g. storm causing entrainment of sulphidic subsurface waters into surface waters), a recurrent seasonal phenomena (due to seasonality in algal growth and thus oxygen consumption or due to seasonal winds and upwelling), or a more permanent phenomena lasting for years to millennia. This distinction among short-lived, recurrent seasonal and longlived hypoxia is critical when studying the benthos and sediment biogeochemistry. Organisms that have evolved in permanently hypoxic setting such as oxygen-minimum zones appear to thrive at very low levels of dissolved oxygen (Childress and Siebel, 1998; Levin, 2003). The effect of oxygen on sediment biogeochemistry depends on the history of the system, as large stocks of reactive components in sediments may delay and attenuate responses to higher or lower oxygen levels (Soetaert et al., 2000). For instance, coastal sediments with active faunal communities and iron and manganese cycles respond differently to low-oxygen conditions than do sediments rich in sulphide and lacking oxidants other than sulphate.

This review aims to synthesize the understanding of biogeochemical processes affected by coastal hypoxia. We will discuss the direct and indirect effects of hypoxia on sediment biogeochemistry and sediment-water exchange fluxes. These processes have been studied extensively and it is beyond the scope of this review paper to cover the entire literature or all aspects. Our goals are (1) to provide a systematic and concise overview of the effect of oxygen on sediment biogeochemistry, both direct and indirect via its effect on benthic faunal communities, and (2) to explore the dynamics and response of sediment biogeochemistry both in terms of sensitivity to and resilience to (recovery from) hypoxic events. We will not cover the consequences of hypoxia on benthic primary producers because our overview is restricted to sediments not receiving sunlight (Larson and Sundbäck, 2008; Montserrat et al., 2008). Gooday et al. (2009) discuss the formation, preservation and use of proxies in hypoxia research and cover in detail the effect of hypoxia on trace element sediment geochemistry. Naqvi et al. (2009) discuss the production and emission of radiatively active gases from hypoxic areas. Levin et al. (2009) review the effect of natural and human-induced hypoxia on benthic communities and Kemp et al. (2009) discuss coastal-hypoxia responses to remediation. These complementary issues will not be repeated here. Rather, we present the direct effect of bottom-water oxygen concentrations on sediment biogeochemistry and organic matter, the indirect effect of oxygen on sediment biogeochemistry via the influence of hypoxia on animals and the implications for sediment and coastal ecosystem dynamics.

\section{Bottom-water oxygen controls on sediment biogeochemistry}

\subsection{Sediment biogeochemistry in oxic settings}

Biogeochemical processes in marine sediments are intimately linked to processes and conditions in the water column: they are fueled by deposition of materials from the water column (e.g. labile organic matter) and are affected by the composition of bottom waters (Berner, 1980; Soetaert et al., 2000; Burdige, 2006). Biogeochemical conditions and processes in coastal sediments differ from those in the water column because of differences in transport processes (molecular versus eddy diffusion and particle settling versus bioturbational mixing), relevant time scales and availability of particulate and dissolved substances. Deposition of labile and reactive materials from the water column provides energy and nutrients for heterotrophic consumers inhabiting marine sediments. The majority of the organic matter deposited is processed by a diverse community of microbes, protozoans and metazoans and only a small part is eventually buried due to sediment accretion (Hedges and Keil, 1995; Middelburg and Meysman, 2008).

The organic material processed is assimilated by heterotrophic organisms (secondary production) or respired and mineralized. As a consequence of high oxygen consumption rates and slow transport of oxygen by molecular diffusion or bio-irrigation (Meysman et al., 2006), oxygen penetration depths are very limited, varying from less than $1 \mathrm{~mm}$ in active, muddy sediments to a few $\mathrm{cm}$ in permeable, sandy sediments (Glud, 2008). Hypoxic and anoxic conditions are thus the norm for the biologically-active upper decimeter(s) of sediments. Oxygen limitation initiates a cascade of alternative electron acceptor use by anaerobic organisms (mainly microbes). Following oxygen depletion, anaerobic respiration is sequentially based on nitrate, manganese and iron (hydr)oxides and sulphates (Fig. 1). This 


\section{Redox Cascade in Oxidants Use and Re-Oxidation}

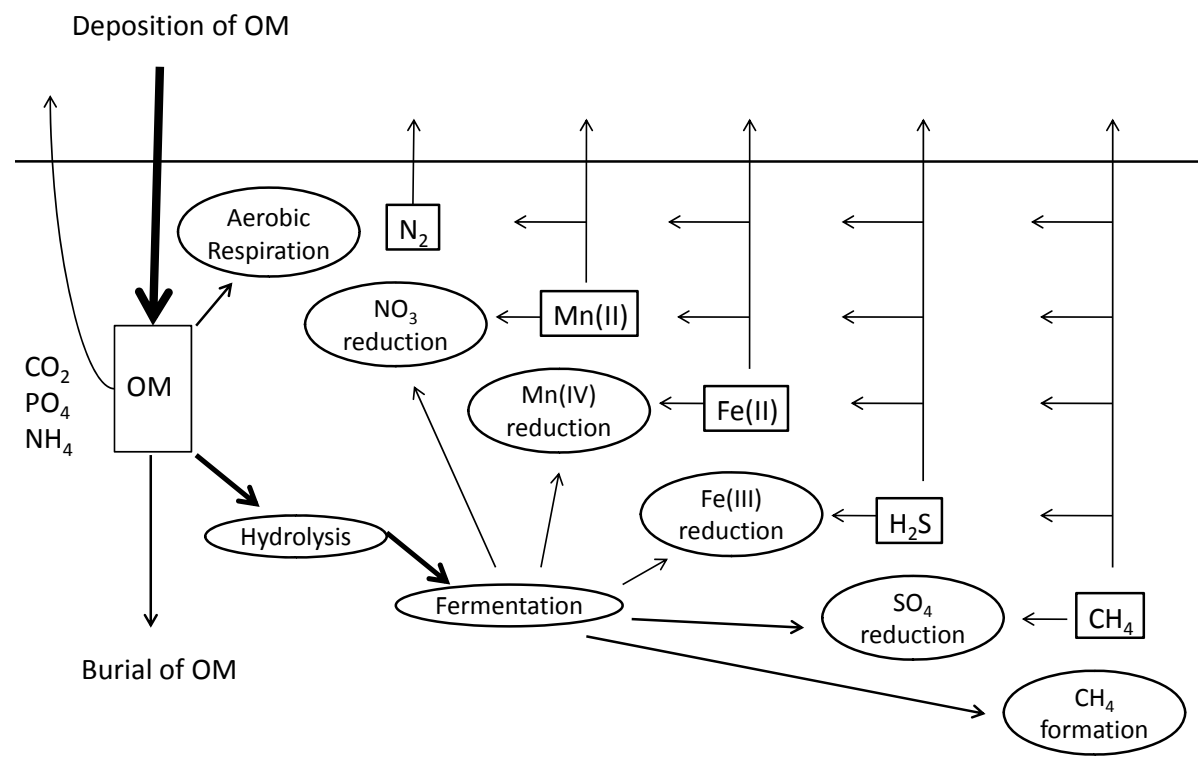

Fig. 1. Conceptual model of organic matter $(\mathrm{OM})$ degradation pathways and re-oxidation pathways in marine sediments. Organic matter degradation involves hydrolysis of macromolecular organic matter and fermentation to smaller compounds. These fermentation products are used by respiring micro-organisms and methanogens. Oxidants are utilized sequentially, first oxygen, then nitrate, metal oxides and sulphate. Dissolved reduced products (methane, sulphide, manganese (II) and iron (II)) diffuse upwards and are then oxidized. Some anaerobic reoxidation pathways may not yet have been documented or unequivocally shown to be microbial mediated. However, anaerobic oxidation of methane by sulphate (Boetius et al., 2000) and nitrate (Raghoebarsing et al., 2006), and sulphide by metal oxides (Aller and Rude, 1988) and nitrate (Jørgensen, 2006) has been reported.

sequence is ultimately governed by thermodynamic energy yield, but it also depends on reaction kinetics and physiology of the micro-organisms involved (Burdige, 2006). If all oxidants have been consumed, organic matter is anaerobically respired and fermented with the result that methane is generated.

Mineralization of organic matter, in particular anaerobic respiration, results in the formation of various reduced substance such as ammonium, iron (II), manganese (II), hydrogen sulphide and methane (Fig. 1). These reduced substances are normally efficiently re-oxidized within sediments because they contain a substantial amount of energy that was originally contained in the organic matter (Jørgensen, 1982). This guarantees optimal use of energy resources at the ecosystem level. Ammonium production from organic nitrogen mineralization can be oxidized aerobically by bacteria and archaea (Wüchter et al., 2006) or anaerobically by bacteria (Anammox; Strous and Jetten, 2004). Dissimilatory reduction of particulate metal oxides causes release of reduced iron and manganese in dissolved form. These are in turn efficiently oxidized by microbes using oxygen or nitrate as electron acceptors. Sulphate is the second most abundant anion in seawater and sulphate reduction thus accounts for the majority of (anaerobic) mineralization in coastal sediments (Jørgensen, 1977, 1982, 2006; Soetaert et al., 1996). The sulphide generated partly reacts with reactive iron (dissolved or particulate) to form iron sulphide (initially acid volatile forms and eventually pyrite). Another part of the sulphide generated will react with organic matter (Ferdelman et al., 1991; Brüchert, 1998; Werne et al., 2008) or will end-up in the oxidative S-cycle. This involves multiple steps of partial oxidation to intermediates, some of which are disproportionated, i.e. splitting of inorganic molecules into a more reduced and oxidized compounds (Jørgensen, 2006). These intermediate sulfur compounds will stimulate pyrite formation or react with sedimentary organic matter (Damsté and de Leeuw, 1990; Werne et al., 2008). Normally, the iron sulphide minerals and organic sulphur formed in coastal sediments are also oxidized efficiently and then integrated into the oxidative sedimentary S cycle (Jørgensen, 1977). The efficiency of this part of the sulphur cycle depends on bioturbation (faunal mixing) of reduced particulate sulphur and non-steady state diagenetic processes stimulating contact between reduced and oxidized compounds (Berner and Westrich, 1985). Re-oxidation of reduced sulphur compounds may involve oxygen, nitrate, metal oxides or more oxidized sulphur compounds (Jørgensen, 2006). Finally, the methane produced in sediments can be oxidized aerobically, but the majority is oxidized anaerobically involving consortia of bacteria and archaea (Boetius et al., 2000). 


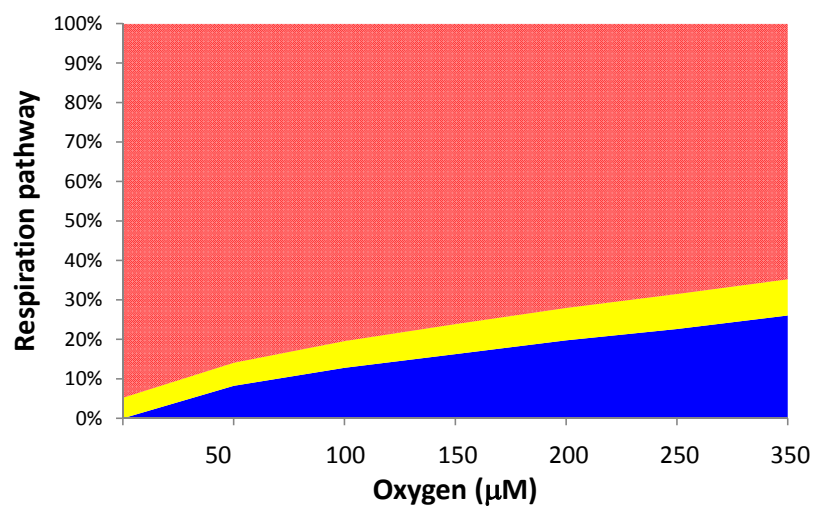

Fig. 2. Partitioning of community respiration among araerobic respiration (blue), denitrification (yellow) and anaerobic respiration (red) as function of bottom-water oxygen. Based on model simulation of Middelburg et al. (1996).

Anaerobic mineralization dominates in most coastal sediments because of high carbon loading, creating oxygen demands that are not balanced by oxygen supply (Soetaert et al., 1996). The associated high production rate of reduced compounds implies a high demand of oxygen for reoxidation processes. In fact, most of the oxygen consumption in coastal sediments can be attributed to re-oxidation processes with typically less than $25 \%$ of the oxygen consumption being due to aerobic respiration processes (Jørgensen, 1982; Heip et al., 1995; Soetaert et al., 1996; Glud, 2008). This limited importance of aerobic respiration processes for organic matter mineralization does not imply that bottomwater oxygen, and thus hypoxia, have limited impact on diagenetic pathways (Fig. 2). In fact bottom-water oxygen availability is one of the main factors governing diagenetic pathways, sediment biogeochemistry and sediment-water exchange fluxes, as well as the animal communities that influence these processes.

\subsection{The effect of oxygen on diagenetic pathways and sediment-water exchanges}

While discussing the effect of bottom-water oxygen concentration on diagenetic pathways, it is instructive to distinguish among oxic, hypoxic and anoxic settings (Fig. 3) and between hypoxic settings with low and high nitrate. Oxic settings, i.e. coastal sediments underlying oxic $\left(>63 \mu \mathrm{M} \mathrm{O}_{2}\right.$; $>2 \mathrm{mg} \mathrm{O}_{2} / \mathrm{l} ;>1.4 \mathrm{ml} \mathrm{O}_{2} / \mathrm{l}$ ) bottom waters, are characterized by aerobic respiration by microbes and metazoans and re-oxidation of reduced components by oxygen as well as alternative oxidants. In hypoxic settings $\left(<63 \mu \mathrm{MO}_{2}\right.$; $\left.<2 \mathrm{mg} \mathrm{O}_{2} / \mathrm{l} ;<1.4 \mathrm{ml} \mathrm{O}_{2} / \mathrm{l}\right)$ aerobic respiration and aerobic re-oxidation processes are diminished, but anaerobic reoxidation processes still operate based on nitrate and sulphate influxes and sedimentary stocks of metal oxides. In permanently anoxic settings (zero oxygen) and sulphidic settings (zero oxygen and measurable free sulphide), sulphate reduction and methanogenesis dominate mineralization because stocks of particulate oxidants have been exhausted (see below for an explanation) and anaerobic oxidation of methane coupled to sulphate reduction is the only major re-oxidation processes (Fig. 3).

Bottom-water oxygen levels have a direct influence on rates of sediment oxygen consumption, aerobic respiration and re-oxidation reactions because oxygen gradients across the sediment-water interface are smaller at low oxygen concentrations (Fig. 4a). This dependence of sediment oxygen uptake on sediment oxygen concentrations has been observed on the Louisiana shelf (Rowe et al., 2002, 2008), in the Black Sea (Friedl et al., 1998) and along the ocean margin off Washington State and Mexico (Hartnett and Devol, 2003) although the overriding control of carbon deposition may mask oxygen dependencies. Moreover, an oxygen dependency is also consistent with global-scale empirical relations (Cai and Reimers, 1995) and theoretical predictions based on the simple models incorporating zero-order uptake kinetics and diffusive transport (Bouldin, 1968).

The contribution of denitrification to organic matter mineralization is rather constant among oxic, hypoxic and anoxic settings (Fig. 2), but the individual nitrogen species do show a significant dependence on bottom-water oxygen levels. Ammonium effluxes increase significantly when oxygen concentrations decline (Fig. 4c), because less of the ammonium produced is re-oxidized (i.e. nitrified). Higher ammonium effluxes under hypoxic conditions have been reported for a number of settings; e.g. Chesapeake Bay (Kemp et al., 1990, 2005), the Louisiana shelf (Childs et al., 2002; McCarthy et al., 2008) and Danish coastal systems (Conley et al., 2007). These higher ammonium effluxes are not only due to less efficient nitrification due to hypoxia, but may also be related to higher mineralization rates and elevated levels of dissimilatory nitrate reduction to ammonium (DNRA; McCarthy et al., 2008). Bottom-water oxygen also has a significant effect on nitrate fluxes, but it depends on the bottomwater nitrate concentration (Fig. 4b; Middelburg et al., 1996). In some hypoxic settings low oxygen bottom-waters are accompanied by high nitrate concentrations (e.g. eastern $\mathrm{Pa}-$ cific borderland basins and shelves), whereas in some other settings low-oxygen bottom waters are also low in nitrate because it has been consumed already. While most sediments in oxic settings are a source of nitrate to overlying water, they turn into nitrate sinks at low oxygen levels (Fig. 4b). Hypoxic settings with high-nitrate bottom waters are a stronger sink than those with low-nitrate bottom waters. This oxygendependent switch between sediments acting as a sink and source for bottom-water nitrate is a clear example of how ecosystem functions may respond non-linearly to changing bottom-water conditions.

Rates of denitrification either show a limited dependence on bottom-water oxygen or decrease with decreasing oxygen levels (Fig. 4d). This decrease in sedimentary dinitrogen 


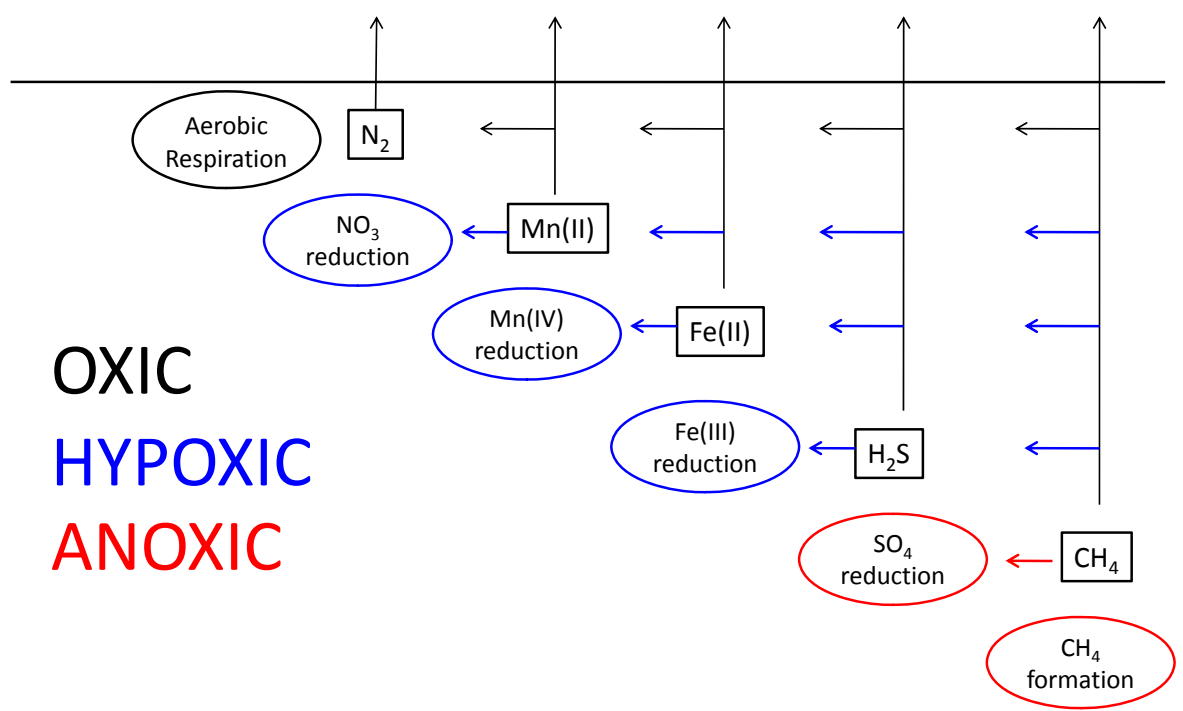

Fig. 3. Conceptual picture of organic matter degradation and re-oxidation pathways in oxic, hypoxic and anoxic marine sediments. Sediments underlying oxic bottom waters support aerobic respiration and re-oxidation of $\mathrm{Mn}$ (II), $\mathrm{Fe}$ (II), $\mathrm{H}_{2} \mathrm{~S}_{\text {and }} \mathrm{CH}_{4}$ by oxygen; these processes do not occur in hypoxic and anoxic sediments. In sediments underlying permanently anoxic bottom waters reactive manganese and iron oxides stocks have been exhausted and organic matter degradation occurs by sulphate reduction and methane formation. While most of the methane formed is oxidized anaerobically, hydrogen sulphide may escape the sediments and enter the water column as has been reported in some systems.

production at low bottom-water nitrate levels can be attributed to a decrease in aerobic nitrification that can only be partly compensated by nitrate influxes (Fig. 4b). Consequently, in hypoxic systems where bottom-water nitrate concentrations are very low, nitrate influxes can not compensate for decreases in aerobic nitrification and sedimentary denitrification may become very low (Kemp et al., 1990, 2005). In anoxic systems with no nitrate in the bottom-water, denitrification is consequently absent and most nitrogen is recycled in the form of ammonium. This ammonium is then oxidized aerobically or anaerobically at redox boundaries in the water column. Lam et al. (2007) reported anaerobic ammonium oxidation (anammox) coupled to archaeal and bacterial nitrification in the Black Sea basin.

The contribution of particulate oxidants such as manganese- and iron-oxides to organic matter mineralization depends in a complex way on sediment organic carbon loading, rates of particle mixing (bioturbation) and bottom-water oxygen levels (Thamdrup, 2000; Burdige, 2006). As oxygen concentrations in the bottom water decrease, the thin oxygenated surface layer of sediment decreases in thickness with the result that manganese (II) and iron (II) diffusing from more reduced layers at depth are less efficiently oxidized in oxygenated surface layers. Consequently, a large proportion of dissolved manganese and iron can escape to bottom waters (Sundby and Silverberg, 1985; Konovalov et al., 2007; Pakhornova et al., 2007). Less re-oxidation, hence less precipitation of manganese and iron oxides, lowers the recycling efficiency and thus the contribution of metal oxides to organic matter degradation. Moreover, the escape of dissolved manganese (II) and iron (II) eventually results in sediments in hypoxic settings that are depleted in manganese and iron relative to sediments in oxic settings (Wijsman et al., 2001; Konovalov et al., 2007). Manganese-oxides are utilized at higher redox levels than iron-oxides (because of thermodynamics); manganese (II) is chemically oxidized less efficiently than iron (II) (because of kinetics) and manganese oxidation requires microbial mediation (Burdige, 2006). As a consequence of these differences in basic chemistry, manganese effluxes and depletion of sedimentary manganese stocks occur at higher bottom-water oxygen levels than those of iron (Kristensen et al., 2003; Kristiansen et al., 2002). Another difference between sedimentary iron and manganese cycling and their dependence on oxygen relates to interactions with the sulphur cycle; these interactions are strong for iron and weak for manganese. Manganese oxide reduction can be coupled to oxidation of reduced sulphur compounds (Aller and Rude, 1988), but precipitation of manganese sulphides is unusual (e.g. Suess, 1979), whereas iron sulphide formation is one of the most common and important biogeochemical processes in sediments (Berner, 1984).

Sulphate reduction generates sulphide that can react with reactive iron compounds to form insoluble iron sulphides such as pyrite. Incorporation of reduced iron in pyrite and other sulphide minerals results in less efficient iron recycling. The dependence of iron effluxes and recycling efficiencies on bottom-water oxygen is non-linear (Fig. 5). Under anoxic 

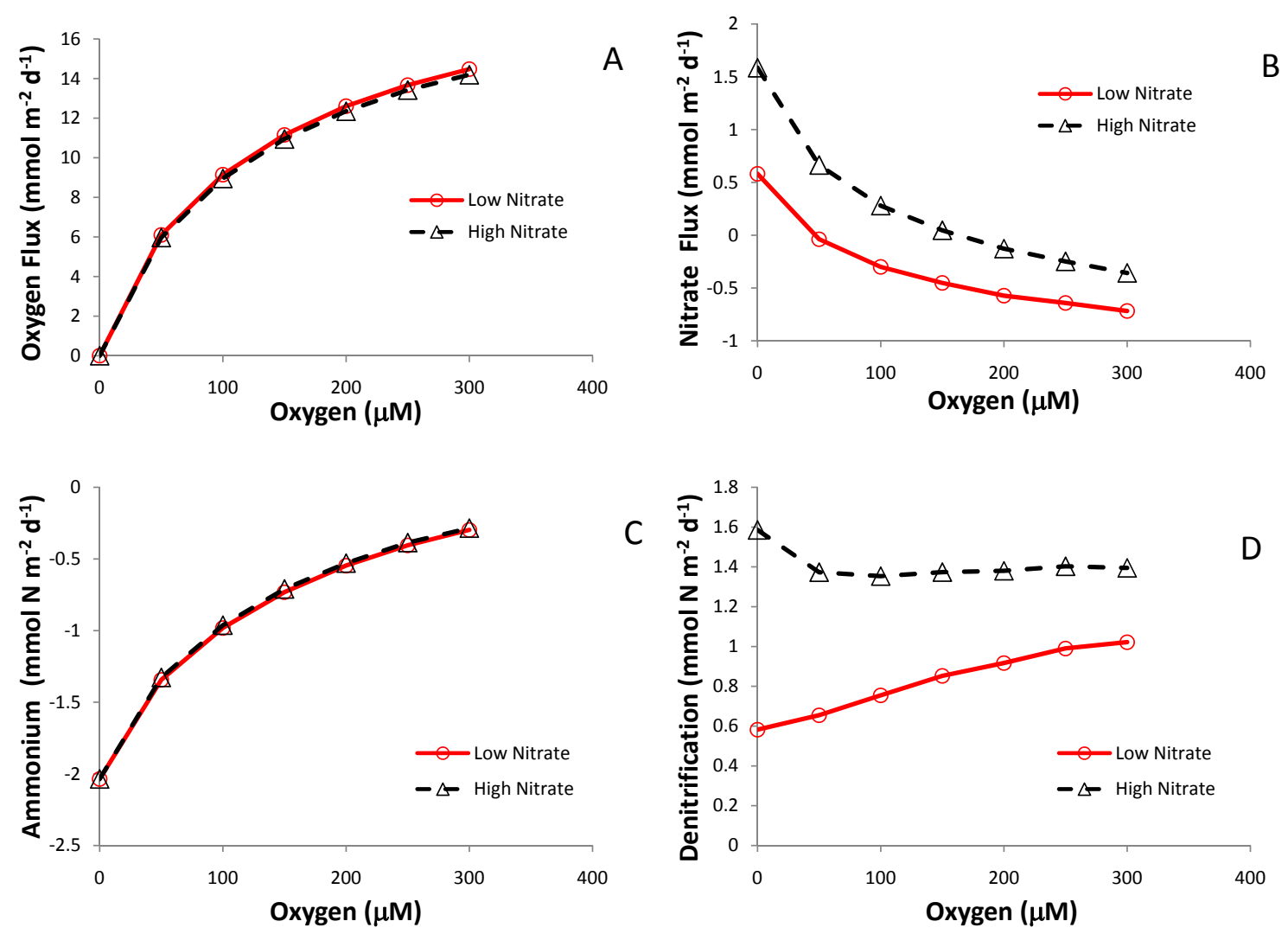

Fig. 4. Fluxes of oxygen (A), nitrate $(\mathbf{B})$ and ammonium $(\mathbf{C})$ and rates of denitrification $(\mathbf{D})$ as a function of bottom water oxygen concentrations for coastal sediments in low $(10 \mu \mathrm{M})$ and high $(30 \mu \mathrm{M})$ bottom-water nitrate settings. Positive fluxes indicate uptake and negative fluxes release from sediments (Middelburg et al., 1996).

bottom waters, iron recycling is limited because of trapped iron in sulphide minerals. Increasing levels of oxygen in bottom waters increases iron recycling efficiencies from about 0.5 in anoxic systems (each mole of iron oxides arriving at sediment surface is used only once) to 0.9 in fully oxic systems, where each iron molecule is cycled many times between the zone of iron reduction at depth and iron oxidation in the surface layer (Fig. 5). This recycling efficiency primarily depends on bottom-water oxygen levels (Wijsman et al., 2001) and rates of bioturbation (Sundby and Silverberg, 1985; Canfield et al., 1993; Thamdrup, 2000). Iron effluxes are maximal under hypoxic conditions because iron is trapped at lower oxygen levels and efficiently recycled and retained within sediments at higher oxygen levels (Pakhomova et al., 2007). The manganese and iron mobilized from hypoxic sediments are often transported laterally to either more oxic settings where oxidation, precipitation and thus settling occurs or to fully anoxic settings where iron can be trapped by reaction with dissolved sulphide (Sundby and Silverberg, 1985; Wijsman et al., 2001; Severmann et al., 2008). This shuttle of iron and manganese from hypoxic to oxic or anoxic settings results not only in iron and manganese depletion of hypoxic sediments, but also in manganese enrichment

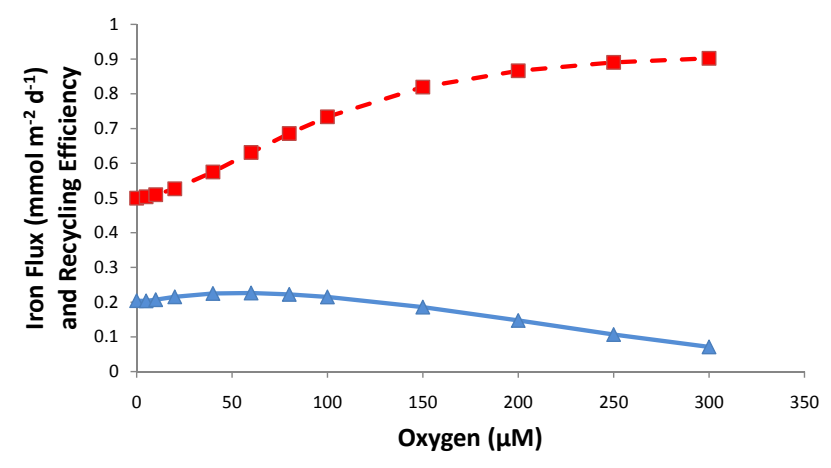

Fig. 5. Sediment iron efflux (blue line with triangles) and recycling efficiency (red dashed line with squares) as a function of bottomwater oxygen for coastal sediments (based on Wijsman et al., 2001).

in oxic settings (Sundby and Silverberg, 1985) and iron enrichment in anoxic settings (Wijsman et al., 2001; Anderson and Raiswell, 2004; Severmann et al., 2008).

Phosphate and trace elements such as arsenic that are intimately linked to iron oxides are consequently also sensitive to bottom-water oxygen levels. The sedimentary phosphorus 
cycle involves degradation of organic phosphorus, interaction of phosphate with sedimentary iron oxides, dissolution of fish debris and formation of authigenic apatite (Sundby et al., 1992; Slomp et al., 1996). The recycling efficiency of phosphate within sediments depends strongly on the availability and cycling of iron oxides. Since the iron oxides with which phosphorus is associated show a strong dependence on bottom-water oxygen levels, a similar strong dependence is observed for phosphate. High fluxes of phosphate usually occur concurrently with high fluxes of iron, either naturally or experimentally induced (Sundby et al., 1986), but not always because of iron trapping by sulphides. High phosphate fluxes under hypoxic and anoxic conditions have been reported for ocean-margin settings (Ingall and Jahnke, 1997), large to intermediate coastal hypoxia such as found in the Chesapeake Bay (Kemp et al., 2005; Jordan et al., 2008), the Baltic Sea (Conley et al., 2003, 2009) and in smaller coastal systems (Rozan et al., 2002). This oxygen dependency of phosphorus cycling has received much attention since the 1940's (Mortimer, 1941) because of its implication for eutrophication and Earth System dynamics (Wallmann, 2003; Slomp and van Cappellen, 2007).

The effect of bottom-water oxygen on sulphur cycling is primarily related to the oxidative part of the sedimentary Scycle because sulphate reduction dominates anaerobic mineralization in most coastal sediments (Fig. 2; Jørgensen, 1982; Soetaert et al., 1996; Burdige, 2006). Lower bottom-water oxygen levels result in less oxidation of particulate and dissolved reduced sulphur compounds with the result that more reduced sulphur is buried (high sulphide retention efficiency; Canfield, 1994; Passier et al., 1997) and that sulphide may escape from the sediments to the water column (Brüchert et al., 2003; Lavik et al., 2009). Hydrogen sulphide release from anoxic sediments has been reported for permanently anoxic systems such as the Black Sea and Cariaco basin as well as for more dynamic settings experiencing hydrogen-sulphide release events (Namibian coastal upwelling, Brüchert et al., 2003, Lavik et al., 2009; the Indian shelf, Naqvi et al., 2006). Recently, Lavik et al. (2009) reported detoxification of sulphidic waters from the Namibian shelf by chemolithotrophs (of the $\gamma$-and $\beta$-proteobacteria) in the water column that completely consumed the sulphide and created a buffer zone between toxic, sulphidic subsurface waters and oxic surface waters. Sediment underlying hypoxic waters with high nitrate concentrations may support microbial communities comprised of large, nitrate-storing bacteria such as Beggiatoa spp. Thiomargarita spp. and Thioploca spp. that couple nitrate reduction to reduced sulphur oxidation (Schulz and Jørgensen, 2001; Brüchert et al., 2003) These sulphur oxidizing, nitrate-storing bacteria often occur at high densities forming thick mats that blanket the sediments. These mats represent specific hypoxic ecosystems that reduce sulphide effluxes and host specialized protozoan and metazoan fauna (Brüchert et al., 2003; Bernhard et al., 2000). Moreover, these giant bacteria also appear to a play a major role in phosphorus cycling as they facilitate formation of authigenic apatites in hypoxic and anoxic sediments (Schulz and Schulz, 2005).

\section{The effect of bottom-water oxygen on sedimentary or- ganic matter}

The question of whether organic matter is better preserved under conditions of anoxic bottom water has been much debated in geosciences because of its relevance for understanding the functioning of Earth system in the past and the formation of oil source rocks (DeMaison and Moore, 1980; Pedersen and Calvert, 1990). Much of the discussion has focused on unraveling and assessing the relative importance of bottom-water oxygen levels and high carbon inputs (i.e. primary production) to organic carbon burial in marine sediments (Tyson, 1995). These two governing factors are often difficult, if not impossible, to disentangle, because high organic matter loadings usually induce hypoxic or anoxic conditions in bottom waters and hypoxia induces enhanced ammonium and phosphate effluxes (see Sect. 2.2) that may sustain high rates of primary production. The intense debate and many studies have resulted in a large body of knowledge and much correlative, but unfortunately often inconclusive, evidence. However, the accumulated evidence appears to favor enhanced preservation potential under hypoxic to anoxic bottom waters (Moodley et al., 2005).

Organic matter burial efficiencies (fraction of organic matter buried relative to organic matter delivery to sediments) correlate strongly with sediment accumulation rates but at low to intermediate sediment-accumulation rates burial efficiencies are often higher in anoxic and hypoxic than in oxic settings (Canfield, 1989, 1994; Middelburg, 1991; Middelburg et al., 1993; Hedges and Keil, 1995), but not always (Cowie et al., 1991). Similarly, the organic-matter burial efficiency correlates strongly with oxygen-exposure time, a measure of the depth of oxygen penetration normalized to sediment- accumulation rates (Hartnett et al., 1998; Hedges et al., 1999). Oxygen exposure scales linearly with bottomwater oxygen concentrations and organic matter burial efficiency thus depends on bottom-water oxygen. Organic matter content of marine sediments depends strongly on sediment texture (i.e. fine grained sediments have higher organic matter contents). Comparison of sedimentary organic matter across gradients and systems (e.g. along the continental margin and river-ocean continuum) therefore requires normalization (Mayer, 1994). The most common method is to express the organic content per unit specific surface area (OC/SS; Mayer, 1994; Hedges and Keil, 1995; Hedges et al., 1999). The rationale is that organic carbon contents correlate with specific surface area in sediments underlying oxic bottom waters and that additional organic carbon, i.e. organic carbon above the mono-layer equivalence ( $\sim 0.5$ to $1 \mathrm{mg} \mathrm{C} \mathrm{m}^{-2}$; Mayer, 1994), reflects enhanced preservation. In a detailed 

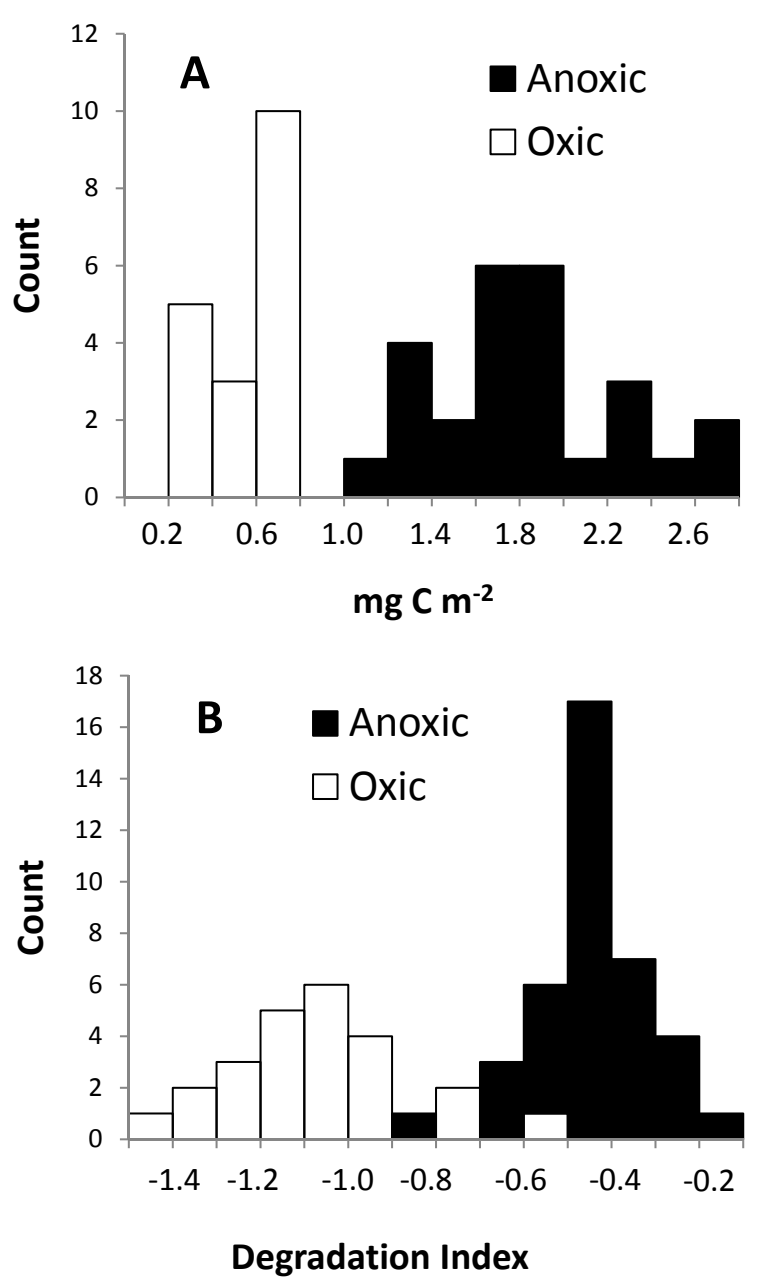

Fig. 6. The effect of oxygen on organic carbon to specific surface areas (A) and organic matter quality as reflected in the amino acid based degradation index (B). These data are based on sediment samples collected above, within and below the ocean minimum zone of the Arabian Sea (Vandewiele et al., 2009).

study of changes in sediment organic matter across the Pakistan margin oxygen minimum zone (OMZ: 140-3200 m), Vandewiele et al. (2009) reported higher organic carbon contents per unit surface area in sediments underlying hypoxic and anoxic bottom water (Fig. 6a). Moreover, organic carbon contents were not correlated with surface areas as observed in oxic settings (Vandewiele et al., 2009). However, for the same sediments, Cowie et al. (2009) demonstrated variability in organic carbon content that was unrelated to oxygen, with the occurrence of maximal organic carbon contents under relatively oxidizing conditions towards the lower OMZ boundary (rather than at the OMZ core). These results indicate that factors other than oxygen contribute significantly as controls on organic carbon preservation (Cowie, 2005).

Such elevated OC/SS ratios in hypoxic and anoxic settings (Fig. 6a) imply a somewhat lower organic matter processing efficiency at low oxygen levels. First-order degradation rate constants for oxic and anoxic degradation both show a significant relationship with the square of sediment accumulation rates (Toth and Lerman, 1977; Reimers and Suess, 1983), but with an offset between oxic and anoxic degradation. This offset might suggest more efficient mineralization under oxic conditions, but this interpretation has been questioned because of differences in methodology and differences in the age of the material degraded (Middelburg et al., 1993). Anaerobic mineralization normally occurs after aerobic mineralization and thus involves the less labile compounds remaining. There have been many laboratory investigations in which the same organic material has been subjected to oxic and anoxic conditions. Most of these studies observed that degradation rates of labile organic matter are similar under oxic and anoxic conditions (e.g. Lee, 1992; Westrich and Berner, 1984). However, there is convincing evidence that refractory compounds require oxygen to be degraded (e.g. Kristensen et al., 1995). Hulthe et al. (1998) incubated surface and subsurface sediments from a depositional coastal environment and found that more refractory, older material may degrade faster when exposed to oxygen, in particular at low overall mineralization rates (Dauwe et al., 2001). Moodley et al. (2005) confirmed this oxygen dependence for ancient organic-rich layers from the Mediterranean and also showed that sulphide accumulation may inhibit mineralization. Moreover, reaction of sulphide (or intermediate sulphur compounds) with organic matter may enhance the preservation potential of organic matter (Damsté and de Leeuw, 1990). Aller (1994) and Aller and Aller (1998) provided convincing evidence that alternating oxic-anoxic conditions result in more extensive mineralization than permanently anoxic conditions. Intermittent oxygen exposure may result from alternating bottom-water conditions and animal activities within sediments, including intermittent bioirrigation and particle transport from subsurface to surface layers.

Laboratory investigations of oxygen influence on degradation are typically of limited duration (i.e. incubations lasting from days to few months) and involve modification of in situ conditions (slurry of plug incubations). Nature has provided us with a few natural experiments in the deep sea that have revealed convincing evidence for a major effect of bottomwater oxygen on organic matter preservation. Wilson et al. (1985) reported that organic matter in a relict deep-sea turbidite from the Madeira abyssal plain exhibited little degradation over a $140000 \mathrm{yr}$ period when exposed to sulphate, but that $80 \%$ of the carbon was respired within $10000 \mathrm{yr}$ in the presence of oxygen. Similarly, Mediterranean sapropels that have been deposited during periods with lower bottomwater oxygen concentrations showed rapid post-depositional degradation of organic matter once normoxic bottom-waters were re-established (Thomson et al., 1999; Moodley et al., 2005). 
Woulds et al. (2007, 2009) and Andersson et al. (2008) experimentally investigated the dependence of carbon processing, including respiration, on bottom-water oxygen concentrations across an oxygen-minimum zone. They added ${ }^{13} \mathrm{C}$ labeled phytodetritus to intact Pakistan margin sediments containing live benthos (140 $\mathrm{m}$ to $1800 \mathrm{~m}$ ) and traced the transfer of ${ }^{13} \mathrm{C}$ to dissolved inorganic carbon, a measure of respiration, and to heterotrophs (bacteria, foraminifera and macrobenthic invertebrates). Phytodetritus processing was observed at all oxygen levels, but respiration rates were somewhat lower under hypoxic than oxic conditions. However, this oxygen effect on respiration (based on dissolved inorganic carbon release) was secondary to the effect of temperature on respiration (Andersson et al., 2008). Bottomwater oxygen however, had a strong effect on the identity of the organisms involved in carbon processing, with diminished metazoan contributions and greater foraminiferal contributions to carbon assimilation at reduced oxygen concentrations (Woulds et al., 2007). Based on faunal responses to oxygen shifts in time and space, they suggested an oxygen threshold between 5 and $7 \mu \mathrm{M}$ for the shift from foraminiferan/bacterial dominance of carbon processing to a significant macrofaunal contribution.

Most research on the effect of oxygen on sediment organic matter has focused on the quantity of organic matter buried, but there are also significant effects on the nature and quality of the organic matter preserved. Geologists have studied the hydrogen index as a measure for preservation of organic material and have reported elevated hydrogen indices in sediments underlying hypoxic or anoxic waters (Cowie, 2005). Most biomarkers (organic molecules that serve as a proxy for environmental conditions or biogeochemical processes in the past) are better preserved under anoxic than oxic bottom waters, implying enhanced preservation (Hoefs et al., 2002; Sinninghe Damsté et al., 2002). Vandewiele et al. (2009) studied the amino-acid composition of sediments across the oxygenminimum zone of the Pakistan margin in the Arabian Sea and used the degradation index (Dauwe et al., 1999) to quantify organic matter quality. Sediments deposited under hypoxic conditions were characterized by higher DI values than those deposited under oxic conditions on the shelf and in the deep sea (Fig. 6b). Vandewiele et al. (2009) attributed this difference in organic matter quality to differences in preservation and bacterial processing. Accordingly, sediments deposited under low-oxygen bottom waters are characterized by higher amounts of organic matter that is also of higher quality. However, most examples presented in this section are from oceanmargin and deep-sea environments, i.e. more stable deposition regimes, and it remains to be seen whether bottomwater oxygen concentrations play such a prominent role in dynamic, alternating oxic-anoxic settings (Aller, 1994). For instance, Hartnett et al. (1998) have shown very high variability (from near zero to $>60 \%$ ) in burial efficiencies of coastal sediments with short oxygen- exposure times.

\section{Bottom-water oxygen, macrobenthos and sediment biogeochemistry}

\subsection{Macrobenthos and sediment biogeochemistry}

Animals living at or in the sediments not only depend on the resources and conditions above and within the sediments, but also modify the texture and geochemistry of their environment (Meysman et al., 2006). Suspension-feeding animals capture food particles from the water column; the labile fraction is used for growth and respiration and a more refractory fraction is deposited in the form of faeces or pseudofaeces. This biodeposition flux of carbon to the seafloor varies spatially due to patchiness in suspension-feeder distributions, can locally dominate carbon delivery to the seafloor and constitutes an efficient coupling of benthic and pelagic processes (Herman et al., 1999). Animals feeding on resources at the sediment surface (surface-deposit feeders) or within the sediment (surface- and subsurface-deposit feeders) have significant effects not only on organic carbon (by consuming it) and other organisms (by grazing and predation), but also via modification of sediment texture and structure, bio-irrigation and particle mixing (Aller and Aller, 1998; Herman et al., 1999; Meysman et al., 2006; van Nugteren et al., 2009). Animals in and on the seabed influence sediment and solute properties. Animals can alter sediment porosity, permeability, particle size, cohesion, and organic content and, perhaps more importantly, their spatial heterogeneity and thus generate niches for smaller organisms (microbes, micro-, meioand macrobenthos) (Aller, 1984; Reise, 1985; Levin et al., 1997; van Nugteren et al., 2009).

Bio-irrigation, the enhanced exchange between pore waters and overlying water column, is the result of active or passive burrow flushing as well as pumping to fluidize sediments to facilitate peristaltic burrowing. Animals living in tubes and burrows flush their burrows to obtain oxygen for respiration (Aller, 2001). Bio-irrigation has many biogeochemical consequences; it results in the enhanced transport of oxygen into the sediments and consequently enhanced rates of aerobic respiration (Archer and Devol, 1992). It also causes enhanced exchange of nutrients and other metabolites, although the actual sign and magnitude depends on a complex number of interacting factors, including the identity, density, and depth distribution of animals (Aller, 2001). For instance, bioirrigation may stimulate nitrification by supply of oxygen, but may also stimulate effluxes of ammonium and nitrate with the result that the net effect on nitrogen cycling (nitrification, denitrification and anammox) depends in a complex way on bio-irrigation (Aller, 2001). Bioirrigation also stimulates patchiness in geochemical conditions and thus can act to maintain biodiversity within the sediment by creating a mosaic of biogeochemical habitats and rate processes (Waldbusser et al., 2004; Waldbusser and Marinelli, 2006). 
Bioturbation, the enhanced dispersal of particles resulting from sediment reworking by burrowing animals, is due to tube construction, burrowing, feeding and relocation of animals (Meysman et al., 2005, 2008). Particle displacement has many consequences for sediment biogeochemistry: e.g. labile organic matter is transported downward and diluted into a larger pool of refractory carbon and metal oxides delivered to or formed in the surface layer may be transported downward to more reduced layers (Sundby and Silverberg, 1985; Thamdrup et al., 1994; Ferro et al., 2003; Burdige, 2006). Conversely, reduced products such as iron sulphide (pyrite) may be mixed from subsurface to surface layers where they are then oxidized by oxygen, nitrate or other oxidants (Berner and Westrich, 1985; Aller and Rude, 1988; Meysman and Middelburg, 2005). Accordingly, sedimentary iron and manganese cycling depend strongly on particle mixing as particulate metal oxides are transferred downwards to more reduced layers and particulate reduced forms (pyrite, manganese carbonates) are mixed upwards to zones of reoxidation (Thamdrup, 2000; Burdige, 2006). Sedimentary sulphur and phosphorus cycles also depend strongly on bioturbation because they are tightly linked to particulate iron phases (see Sect. 2).

Other effects of sediment-dwelling animals include the enhancement of surface biofilms and mucous deposition, which may alter biogeochemical fluxes and create highly reactive substrates. The potential of animals, their exudates and their structures to alter surface roughness, critical erosion velocities and other stability properties (Widdows et al., 2004) all feed back to many of the properties discussed above.

\subsection{Effect of oxygen on macrobenthos and conse- quences for sediment biogeochemistry}

Hypoxia affects the behavior, physiology, and ecology of soft-bottom invertebrate communities in ways that translate ultimately to reduced bioirrigation and bioturbation and loss of structural spatial heterogeneity and surface roughness. While standard definitions of hypoxia are often given, threshold effects vary among taxa, life stages, and settings, and sublethal effects often occur at much higher oxygen levels (e.g. $100 \mu \mathrm{M}$ ) (Vaquer-Sunyer and Duarte, 2008; Levin et al., 2009a, b). At the most fundamental levels, a shift from normoxia to hypoxia will result in migration (away) of large, mobile invertebrates, mortality of selected taxa, emergence and a shallowing of infaunal activities within the sediment column of all but the most hypoxia-tolerant taxa (Pihl et al., 1992; Rabalais et al., 2001a, b; see also Levin et al., 2009). Hypoxia lowers the density and biomass of megafaunal- and selected macrofaunal-size organisms, leading to a smaller community body-size structure (Levin 2003; Quiroga et al., 2005). Echinoderms and most crustaceans are particularly affected by oxygen depletion, while annelids, mollusks and cnidarians are typically more tolerant (Rosenberg et al., 1991; Diaz and Rosenberg, 1995). Because respiration and re-oxidation of reduced compounds typically drives $\mathrm{pH}$ down at the same time it drives oxygen down, animals with carbonate skeletons or shells (e.g. echinoderms and many mollusks) may be negatively affected. Depending on the severity and duration of hypoxia, nearly complete mortality of the benthic fauna can occur in coastal settings seasonally (e.g. Mountford, 1977). However, commonly small macrofauna and meiofauna will persist (Levin, 2003; Neira et al., 2001; Sellanes et al., 2003; Sellanes and Neira, 2006; Sellanes et al., 2007); often these are opportunistic taxa with short generation times (Dauer et al., 1992). Under severe dysoxia or anoxia, filamentous, mat-forming bacteria (Jørgensen and Gallardo, 1999), calcareous foraminifera, nematodes and branchiate, and soft-bodied annelids are typically favored (reviewed in Levin, 2003; Guttierez et al., 2008). High surface area to volume ratios enhance oxygen diffusion; such ratios are imparted by long thin morphologies and masses of tentacles, palps or branchiae (Lamont and Gage, 2000).

Species and functional diversity of benthic faunas are reduced under hypoxic conditions. Reduced species richness is accompanied by high dominance; communities may be comprised of a very few, but highly abundant species. Usually surface-deposit feeders are favored over subsurface or suspension feeders (e.g. Gutierrez et al., 2000; Levin et al., 2000), although some carnivorous, epifaunal species such as polynoid polychaetes may persist. Large sedimentdwelling megafauna such as thalassinid shrimp, echiurans, enteropneusts, and burrowing bivalves and sipunculans are important sources of hetereogeneity, creating multiple microniches for smaller taxa (Reise, 1985). They are lost at reduced oxygen levels and sediment assemblages become much more homogeneous (Levin et al., 2000). Loss of structures formed by foundation species such as seagrass beds (Duarte, 1995; Burkholder et al., 2007), oyster reefs (Breitburg et al., 2001) or mussel beds (Mee et al., 2005) also reduces heterogeneity, curtails benthic-pelagic coupling and exacerbates hypoxia-induced species loss.

The above changes described for sediment communities correspond to reduced rates of solute pumping and particle mixing and a shallowing of irrigation and particle-mixing activities within the sediment column (Aller, 1980; Rhoads and Boyer, 1982; Nilsson and Rosenberg, 2000). At shelf and upper bathyal depths, tube builders often predominate over deep burrowers under hypoxic conditions (Pearson and Rosenberg 1978; Wheatcroft, 1989), but this is not always the case. Animal activities in tubes can aerate the tube interior and surrounding sediments, but surface-deposit feeders dwelling in tubes typically defecate on the surface and carry out less vertical bioturbation than mobile burrowers. Despite the inhibition of burrowers in many hypoxic settings (Pearson and Rosenberg, 1978; Gutierrez et al., 2000), under nearly anoxic conditions, symbiosis allows gutless, burrowing oligochaetes to persist and bioturbate sediments on the Peru margin (Levin et al., 2003). At the extreme, anoxia 
involves a complete halt of bioturbation and the formation of sediment laminae (Rhoads and Boyer, 1982; Schaffner et al., 1992). The palaeo literature is replete with discussion of oxygen effects on trace (ichno) fossils and lamination (Rhoads and Morse, 1971; Savrda et al., 1984; Savrda and Bottjer, 1987, 1991). Trends in abundance, size, diversity and vertical distribution mirror those discussed for modern faunas (see Gooday et al., 2009). Loss of fauna combined with development of thick bacterial mats that inhibit diffusion of oxygen from the overlying water can lead to more stagnant conditions and buildup of microbial wastes (ammonium, sulphide), creating an environment inhospitable to aerobic eukaryotes. However the interplay of oxygen, temperature, sulphide buildup and food availability appears to modulate the responses of benthic communities to specific oxygen conditions (Olenin, 1997; Levin et al., 2009a; Vaquer-Sunyer and Duarte, 2008).

The hypoxia-induced changes in benthic community structure and functioning have major consequences for sediment biogeochemistry via their effects on the intensity and depth distribution of bio-irrigation and particle mixing, and changes in flow dynamics at the sediment-water interface. These interactions among hypoxia, benthos and biogeochemistry are complex and often non-linear (e.g. Aller, 2001). In shallow waters, interface and surface-deposit feeders are generally favored over subsurface-deposit feeders if bottomwater oxygen levels decline (Pearson and Rosenberg, 1978; Levin et al., 2009b). Particle mixing and bio-irrigation are consequently restricted to surface layers of sediment. Consequently, less organic matter is mixed downward and more labile organic matter is degraded at the surface, i.e. within the zone in diffusional exchange with the overlying water. This shortening of diffusion distances implies more efficient regeneration of nutrients (Aller and Aller, 1998). Shallower particle mixing also implies less efficient re-oxidation of iron sulphide formed at depth in the sediment. Sulphide burial and retention efficiencies increase at the expense of reoxidation because the latter requires particle transport from the reduced, deeper to oxygenated, surface layers (Berner and Westrich, 1985). Loss of irrigating animals likely lowers oxygen uptake because their consumption rates are often transport limited in coastal systems with abundant quantities of labile organic matter (Glud, 2008). Whether the loss of bioirrigation activity results in an increase or decrease of ammonium, manganese and iron effluxes is largely unknown and is system-specific because it depends on the balance between reduced re-oxidation (due to reduced oxygen supply) and reduced removal of metabolites by burrow flushing (Aller, 2001). Metabolites may accumulate in pore-waters if bio-irrigation is less or shallower due to hypoxia. Accumulation of metabolites in pore-water may prevent settling of other organisms and in this way have consequences for population dynamics, ecosystem functioning and sediment biogeochemistry (Marinelli and Woodin, 2002).
The consequences of hypoxia-induced macrofauna diversity loss on biogeochemistry are multiple but poorly documented. Many studies have examined the relationship between macrofauna diversity and sediment metabolism or sediment-water exchange fluxes These studies showed that animal-diversity-biogeochemistry relationships are highly complex. They can be linear or non-linear (MermillodBlondin et al., 2005; Norling and Kautsky, 2007), idiosyncratic and depend on the context (Emmerson et al., 2001; Rossi et al., 2008), and vary with species identity, biomass and density (e.g. Aller and Yingst, 1985; Ieno et al., 2006; Waldbusser and Marinelli, 2006; Marinelli and Williams, 2003). Most of these studies were based on analyses of single species or artificially constructed assemblages of species. Recently, Rossi et al. (2008) investigated diversity - biogeochemistry relationships during macrofaunal recovery after deliberately induced anoxia. They showed that differences in diversity due to hypoxia result in differences in sedimentwater exchange fluxes of nutrients. Sediment-water exchange fluxes are governed by the balance between faunagenerated transport processes and microbe-mediated transformation processes (Meysman et al., 2005, 2006). To understand faunal diversity effects on sediment biogeochemistry therefore requires unraveling the effect of fauna on microbes via transport processes and food-web interactions (bacterial grazing), and understanding the feedback of microbes on faunal functioning. For instance, sulphate-reducing microbes generate sulphide that is toxic for many animals or that may impede their functioning (Hargraves et al., 2008), while reduced sulphur oxidizing or sulphur disproportionating bacteria detoxify the sediment so that is habitable for animals (Pearson and Rosenberg, 1978; Levin et al., 2009). Before we can understand the effect of oxygen via metazoan diversity on sediment biogeochemistry, it is necessary to elucidate the many trophic, competitive and non-competitive interactions between fauna and microbes (e.g. competition for labile organic matter, facilitation of transport via bioturbation, creation of niches via burrow construction, grazing etc.; Levin et al., 1997; Meysman et al., 2005, 2006; Rossi et al., 2008, 2009).

\section{Dynamics of sediment biogeochemistry and coastal hypoxia}

\subsection{Pelagic-benthic coupling and coastal hypoxia}

Coastal systems are characterized by the presence of an active benthic component interacting closely with the pelagic compartment (Soetaert et al., 2000). Understanding coastal hypoxia therefore requires not only consideration of sediment and water column biogeochemical processes but also how their coupling changes as a function of bottom-water oxygen conditions. In Sect. 2 we have seen that as bottom-water oxygen levels decrease, aerobic degradation 
and re-oxidation reactions become less important and eventually may take place only in the water column. Initially nitrate may accumulate in hypoxic bottom waters (as observed in low-oxygen waters of the Eastern Pacific Basin) because nitrification in bottom waters (rather than sediments) outbalances enhanced nitrate uptake by the sediments (Soetaert and Middelburg, 2009). However, during prolonged periods of hypoxia, nitrification shallows in the water column and bottom waters become low in nitrate with the consequence that sediment denitrification decreases (Kemp et al., 1990, 2005; Childs et al., 2002). This loss of denitrification implies a higher recycling efficiency of nitrogen at the ecosystem level and may sustain or enhance algal blooms (Kemp et al., 2005). Hypoxia also results in release of manganese (II), iron (II) and elements such as phosphorus that are intimately linked to metal oxides in the water column. These reduced metals are transported to the redoxcline in the water column where (microbial) oxidation occurs (e.g. Black Sea; Konavalov et al., 2006; Lewis et al., 2007; Cariaco Basin; Percy et al., 2008). Part of the phosphate released from sediments will attach to the newly formed iron oxides (Shaffer, 1986), another part may sustain or enhance algal blooms (Rozan et al., 2002; Kemp et al., 2005). This enhanced recycling of ammonium and phosphate under hypoxic bottom-waters may lead to secondary eutrophication phenomena (Cloern, 2001; Kemp et al., 2005), including harmful algal blooms (Ma et al., 2006). This hypoxia-related enhanced regeneration of nutrients, in particular phosphorus, and basin-wide consequences for plankton communities and biogeochemical processes have been very well been documented in the Baltic Sea (Conley et al., 2009).

Little oxidation of reduced sulphur occurs in sediment underlying anoxic bottom waters and part of the hydrogen sulphide escapes sediments and is then oxidized in the water column (Black Sea; Konovalov et al., 2006; Cariaco Basin; Taylor et al., 2001; Delaware Inland Basins; Luther et al., 2004; Mariager Fjord; Zopfi et al., 2001; Namibian shelf; Lavik et al., 2009). This oxidation of reduced sulphur may occur aerobically or anaerobically with nitrate, resulting in an anoxic layer that separates oxic and sulphidic waters (Lavik et al., 2009). Moreover, Konovalov et al. (2003) have reported catalytic manganese oxide cycles in suboxic zones that are important to oxidation of sulphide. These oxidation processes can take place below and in the photic zone. Green pigmented sulphur oxidizing bacteria require light and hydrogen sulphide and are often found in the lower part of the photic zone where hydrogen sulphide diffuses from below (e.g. Black Sea; Overmann et al., 1992; Damsté et al., 1993).

This temporal evolution from oxic, via hypoxic, to anoxic bottom-water conditions and the associated transition of anaerobic respiration and re-oxidation reactions from sediments to the water column can develop over very long times. It eventually results in permanent anoxia as seen in the Black Sea and Cariaco Basin (Damsté et al., 2003), but can also be interrupted by natural (e.g. Baltic Sea; Conley et al., 2002; Peru shelf; Gutierrez et al., 2008; Santa Barbara basin; Sholkovitz and Gieskes, 1971) or deliberately induced oxidation events (Luther et al., 2004). Each interruption of the longer-term evolution to anoxic bottom water results in re-introduction of biogeochemical processes occurring at higher oxidation levels. For instance, advection of oxygenated North Sea water into the Baltic sea anoxic basins results in a cascade of reactions with consequences for nitrogen cycles (Voss et al., 1998), formation of particulate manganese and iron oxides and cycling of phosphorus and sulphur (Yakushev et al., 2007). Similar, responses have been reported for intrusions of Mediterranean water into the upper part of the Black Sea (Glazer et al., 2006). Temporal variability in bottom-water oxygen levels can have major consequences for iron and manganese biogeochemistry of sediments (Lyons et al., 1993; Wijsman et al., 2001; Kristensen et al., 2003), but the nature of the response depends strongly on previous exposure time to hypoxic or anoxic bottom waters.

\subsection{Duration of exposure to hypoxia matters for biogeo- chemical response}

The effect of bottom-water oxygen on sediment biogeochemistry has so far been discussed based on a steady-state concept. However, hypoxia may last from hourly events to centuries and the governing sedimentary biogeochemical processes will be different. Moreover, the response to decreasing or increasing oxygen levels may depend on the initial condition and history of bottom-water oxygen contents. The temporal response to bottom-water hypoxia is similar to the biogeochemical depth distribution observed in sediments underlying oxic bottom waters (Fig. 1). Kristensen et al. (2003) and Kristiansen et al. (2002) studied the response of sandy coastal sediments to hypoxia and observed first manganese reduction and gradual disappearance of manganese oxides, then iron reduction and disappearance of iron oxides and finally release of hydrogen sulphide from the sediments. These controlled laboratory experiments were limited to a one month period. The development of hypoxia in many coastal systems is seasonal, i.e. oxygen concentrations gradually decline after a spring/early summer plankton bloom, remain low for several months and then increase again (Danish coastal systems; Conley et al., 2007; coastal lagoons; Ritter and Montagna, 1999, Rozan et al., 2002; Chesapeake Bay; Officer et al., 1994; Kemp et al., 1990, 2005; Louisiana Shelf; Rabalais et al., 1994, 2001, Eldridge and Morse, 2008; Indian shelf; Naqvi et al., 2000). The decrease in bottomwater oxygen levels may cause a switch from nitrate effluxes to influxes (Kemp et al., 1990; Cowan and Boynton, 1996), a decrease in denitrification during summer because of low nitrate levels in bottom waters (Kemp et al., 1990; Conley et al., 2007), enhanced release of ammonium and phosphate (Cowan and Boynton, 1996; Rozan et al., 2002; Eldridge and Morse, 2008) and eventually hydrogen sulphide 
(a)

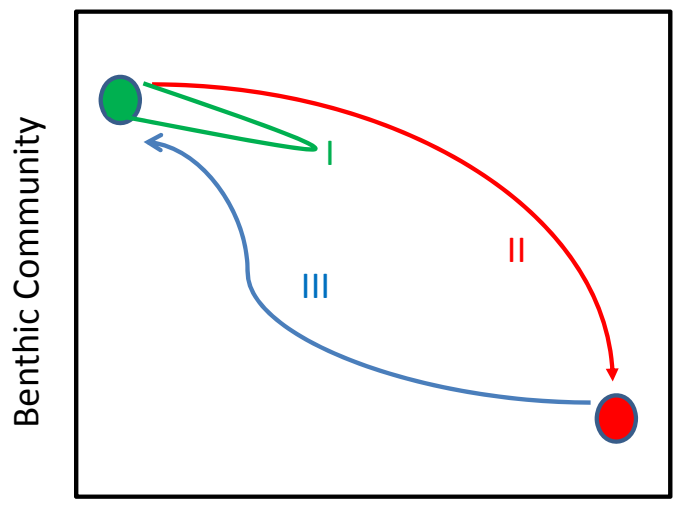

Oxic
Hypoxic
Anoxic

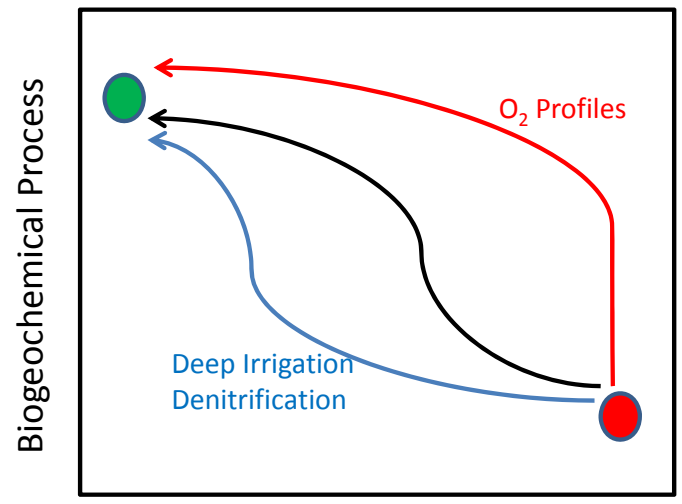

Oxic

Hypoxic

Anoxic

Fig. 7. (a) Conceptual model of benthic community response to hypoxia (based on Diaz and Rosenberg, 2008). Trajectory I occurs when benthos is exposed to moderate hypoxia, trajectory II occurs when animals die upon increasing hypoxia and trajectory III represent the return path from anoxia and involves successional dynamics of fauna. (b) Conceptual model of ecosystem functioning/biogeochemical process recovery following anoxia and associated mortality of organisms.

accumulation in bottom waters (Luther et al., 2004). The duration, intensity and frequency of hypoxia play a major role as coupled nitrification-denitrification can be restored to previous levels during seasonal hypoxia, while after a long period of anoxia (with loss of faunal groups) denitrification will remain low following re-oxygenation of the water column (Hietanen and Lukkari, 2007; Conley et al., 2009).

Katsev et al. (2007) studied the response of St. Lawrence River estuary sediment to progressive oxygen depletion over a decadal timescale. They calibrated a dynamic diagenetic model with data acquired over the last 30 years and then made model projections for the next 80 years (i.e. the period remaining before the system will turn anoxic given presentday decreases in oxygen concentrations). Consistent with short-term and seasonal responses to oxygen depletion, they predicted enhanced accumulation of iron sulphides, effluxes of iron (II) and manganese (II) and rather uniform levels of denitrification (consistent with Figs. 2 and 4). However, model-predicted phosphate effluxes were also rather constant because the seasonal iron-phosphate buffer is not effective and phosphate effluxes balance the differences between phosphorus deposition and burial (Katsev et al., 2007).

This study also highlighted another aspect of sediment biogeochemical response to slowly decreasing oxygen levels in bottom waters; i.e. the time required to reach steady-state is much longer than the actual period of decreasing oxygen levels. This indicates that steady-state approaches should be adopted with some reservation and that diagenetic history influences the actual response. Because of its storage capacity for particulate and dissolved components, sediment is an important reservoir and by slowly exchanging material with the overlying water, may influence long-term system behavior. Soetaert and Middelburg (2009) explored the response of hypoxic coastal systems to lowered nitrogen loadings and concluded that internal nitrogen loading (sediment nitrogen release) delays nitrogen restoration. Similar delays in system recovery to reduced-phosphorus loadings by internal loading in the sediment have been shown for certain lakes (Jeppesen et al., 2005). Turner et al. (2008) investigated the sensitivity of Gulf of Mexico hypoxia to nitrogen loading and observed that organic matter and nitrogen accumulated in sediment from previous years had increased the potential hypoxia development for a given nitrogen input to the system. A similar legacy of eutrophication has been reported for phosphorus loadings in the Baltic Sea (Conley et al., 2002).

\subsection{Dynamics of faunal response to hypoxia and sedi- ment biogeochemistry}

There is an extensive literature on the dynamical response of fauna to hypoxia (Diaz and Rosenberg, 1995, 2008; Levin et al., 2009a), which is beyond the scope of this paper focusing on the consequences for biogeochemistry. However, it is important to recognize and discuss the essential differences in trajectories of benthic communities going from oxic to anoxic conditions and those shifting from anoxia and hypoxia to normoxia. Figure 7a shows a conceptual model based on Diaz and Rosenberg (2008) for the response of benthic communities to increasing hypoxia. Benthic communities exposed to hypoxia of moderate intensity do show signs of community structure change, but upon return of normal oxygenated bottom waters the benthic community returns to 
its initial state (trajectory I in Fig. 7a). This resilience of benthic communities depends not only on the intensity of hypoxia, but also on the temporal and spatial scales of hypoxia. Recovery from small-scale hypoxic events is usually fast because of animal migration (as adults or larvae) from adjacent areas (Norkko et al., 2006). Long-term exposure to severe hypoxia and anoxia causes mortality of animals (trajectory II in Fig. 7a) and most metazoans are eventually eliminated. If the areal cover is extensive, the surroundings can no longer provide source propagules. The recovery trajectory (III in Fig. 7a) from severe hypoxia or anoxia is different than the decline path because the recovery involves successional dynamics (colonizing opportunistic species are eventually replaced by equilibrium species; van Colen et al., 2008; Rossi et al. 2008, 2009). This hysteresis due to macrobenthos mortality and recovery involving succession occurs when the duration and/or intensity of hypoxia is high (Rosenberg et al., 2002). There is thus an oxygen threshold below which hysteresis in macrofauna community recovery occurs. Depending on the system, the duration and intensity of hypoxia, the recovery may take many years (Diaz and Rosenberg, 2008).

During initial stage of hypoxia there are behavioural and physiological adaptations of organism such as shallowing of deposit-feeding organisms (Pearson and Rosenberg, 1995) and enhancement of pore-water ventilation rates to maintain oxygen in the burrows (Forster et al., 1995). These behavioural changes have consequences for bioturbation and bio-irrigation modes, intensities and depth-distribution patterns. However, when the hypoxia threshold has been passed and animals experience mortality, then biologically-induced particle mixing and solute transport rates become zero, with major consequences for sediment biogeochemistry. The reinstallment of bioturbation and bioirrigation during macrofauna recovery has not been studied but these fauna-mediated transport modes will depend on the system-specific successional dynamics. The first colonizers are often small-sized, interface/surface deposit feeders (Rhoads, 1994; van Colen et al., 2008) and bioturbation will consequently be shallow and limited (bioturbation intensity scales with size squared; Meysman et al., 2003). Subsurface- deposit feeders and large, deep-burrowing animals appear later in the recovery trajectory and then bioturbation and bio-irrigation activities are expected to increase. Biogeochemical modellers have employed linear and highly non-linear dependencies of bioirrigation and bioturbation depth and intensities on bottomwater oxygen levels (Morse and Eldridge, 2007; Soetaert and Middelburg, 2009). Katsev et al. (2007) showed that additional knowledge about the response of bioturbation and bio-irrigation to hypoxia is necessary to further our predictive capabilities concerning the effect of oxygen on sediment biogeochemistry.

Biogeochemical dynamics during recovery from severe hypoxia is complicated by a basic lack of knowledge on the return of bioturbation and bioirrigation transport patterns, and on the interaction of fauna with the stock of reduced (sulphur) compounds that have accumulated during anoxic periods. Complete elimination of fauna results in enhanced accumulation and retention of reduced sulphur in sediments. Initial colonizers have to deal with high sulphide concentrations that are toxic to many species and appearance of other species may in part depend on the detoxification of strongly reduced sediments by shallow bioturbators (Pearson and Rosenberg, 1978; Rhoads, 1974) or by sulphideoxidizing microbes. Figure $7 \mathrm{~b}$ shows a conceptual model for recovery of biogeochemical processes following a period of severe hypoxia or anoxia with elimination of animals. Biogeochemical processes that primarily depend on molecular diffusion of dissolved oxidants such as oxygen are expected to become established within one-two days depending on the diffusion distance and the dynamics of the microbes involved. Montserrat et al. (2008) showed that benthic microalgal communities were reestablished within two weeks following anoxia for more than 6 weeks. Biogeochemical processes that depend on interface feeders and shallow bioturbators are expected to recover on time scales of weeks to months, while microbial processes that depend on particle mixing or pore-ventilation by large, deep living animals may need years to fully recover (Fig. 7b). While there are very few data to support or falsify this conceptual model for recovery of biogeochemical processes, it is clear that microbial recovery, despite the inherent fast turnover of microbial populations, may take months because their recovery depends on the return of animal-induced transport processes.

While biogeochemical processes in hypoxic waters and sediments of the coastal zone are complex, they hold great significance for many large-scale phenomenon of concern. On short time scales, cycles of nutrient regeneration, primary, secondary and fisheries production are all affected by biogeochemical pathways. On longer times scales, carbon sequestration and burial and even the formation of energy reservoirs are under biogeochemical control, with microbes as the primary agents of change. As global change brings declining oxygen concentrations in coastal and shelf waters, greater understanding of animal-microbe interactions and feedbacks under different oxygen scenarios, and their mediation of biogeochemical processes, will facilitate predictions, conservation and management of coastal resources.

Acknowledgements. We thank SCOR for supporting the working group 128 and the members of this SCOR working group for exchange of ideas and providing a stimulating environment. Referees G. Luther and G. Cowie and editor W. Naqvi are thanked for constructive feedback. This research was partly funded by the US National Science Foundation, the Netherlands Organisation for Scientific Research and contributions to the EU supported HYPOX project. This is publication 4573 of the Netherlands Institute of Ecology, Yerseke.

Edited by: S. W. A. Naqvi 


\section{References}

Aller, R. C.: Quantifying solute distributions in the bioturbated zone of marine sediments by defining an average micro environment, Geochim. Cosmochim. Ac., 44, 1955-1965, 1980.

Aller, R. C.: The importance of relict burrow structures and burrow irrigation in controlling sedimentary solute distributions, Geochim. Cosmochim. Ac., 48, 1929-1934, 1984.

Aller, R. C.: Bioturbation and remineralization of sedimentary organic matter - Effects of redox oscillation, Chem. Geol., 114, 331-345, 1994.

Aller, R.C. : Transport and reactions in the bioirrigated zone, in: The benthic boundary layer: transport processes and biogeochemistry, edited by: Boudreau, B. P. and Jørgensen, B. B., pp. 269-301, 2001

Aller, R. C. and Rude, P. D.: Complete oxidation of solid-phase sulphides by manganese and bacteria in anoxic marine sediments, Geochim. Cosmochim. Ac., 52, 751-765, 1988.

Aller, R. C. and Yingst, J. Y.: Effects of the marine deposit feeders Heteromastus-Filiformis (Polychaeta), Macoma-Balthica (Bivalvia), and Tellina-Texana (Bivalvia) on averaged sedimentary solute transport, reaction rates, and microbial distributions, J. Mar. Res., 43, 615-645, 1985.

Aller, R. C. and Aller, J. Y.: The effect of biogenic irrigation intensity and solute exchange on diagenetic reaction rates in marine sediments, J. Mar. Res., 56, 905-936, 1998.

Anderson, J. J. and Devol, A. H.: Extent and intensity of the anoxic zone in basins and fjords, Deep-Sea Res. Pt. I, 34, 927-944, 1987.

Anderson, T. F. and Raiswell, R.: Sources and mechanisms for the enrichment of highly reactive iron in euxinic Black Sea sediments, Am. J. Sci., 304, 203-233, 2004.

Andersson, J. H., Woulds, C., Schwartz, M., Cowie, G. L., Levin, L. A., Soetaert, K., and Middelburg, J. J.: Short-term fate of phytodetritus in sediments across the Arabian Sea Oxygen Minimum Zone, Biogeosciences, 5, 43-53, 2008, http://www.biogeosciences.net/5/43/2008/.

Archer, D. and Devol, A.: Benthic oxygen fluxes on the Washington Shelf and Slope - a comparison of I in situ microelectrode and chamber flux measurements, Limnol. Oceanogr., 37, 614-629, 1992

Bagarinao, T.: Sulphide as an environmental factor and toxicant: tolerance and adaptations in aquatic organisms, Aquat. Toxicol., 24, 21-62, 1992.

Berner, R. A.: Early diagenesis: A theoretical approach, Princeton Univ. Press, 1980.

Berner, R. A.: Sedimentary pyrite formation - an update, Geochim. Cosmochim. Ac., 48, 605-615, 1984.

Berner, R. A. and Westrich, J. T.: Bioturbation and the early diagenesis of carbon and sulphur, Am. J. Sci., 285, 193-206, 1985.

Bernhard, J. M., Buck, K. R., Farmer, M. A., and Bowser, S. S.: The Santa Barbara Basin is a symbiosis oasis, Nature, 403, $77-$ 80, 2000.

Boetius, A., Ravenschlag, K., Schubert, C. J., Rickert, D., Widdel, F., Gieseke, A., Amann, R., Jorgensen, B. B., Witte, U., and Pfannkuche, O.: A marine microbial consortium apparently mediating anaerobic oxidation of methane, Nature, 407, 623-626, 2000.

Bouldin, D. R.: Models for describing diffusion of oxygen and other mobile constituents across mud-water interface, J. Ecol., 56, 77-
87, 1968

Breitburg, D. L., Pihl, L., and Kolesar, S. E.: Effects of low dissolved oxygen on the behavior, ecology and harvest of fishes: A comparison of the Chesapeake Bay and Baltic-Kattegat Systems, in: Coastal and Estuarine Studies: Coastal Hypoxia Consequences for Living Resources and Ecosystems, edited by: Rabalais, N. N. and Turner, R. E., American Geophysical Union, Washington, D. C., 293-310, 2001.

Brüchert, V., Jorgensen, B. B., Neumann, K., Riechmann, D., Schlosser, M., and Schulz, H.: Regulation of bacterial sulphate reduction and hydrogen sulphide fluxes in the central Namibian coastal upwelling zone, Geochim. Cosmochim. Ac., 67, 45054518, 2003.

Brüchert, V.: Early diagenesis of sulfur in estuarine sediments: The role of sedimentary humic and fulvic acids, Geochim. Cosmochim. Ac., 62, 1567-1586, 1998.

Burdige D. : Geochemistry of Marine Sediments, Princeton University Press, 2006

Burkholder, J. M., Tomasko, D. A., and Touchette, B. W.: Seagrasses and eutrophication, J. Exp. Mar. Biol. Ecol., 350, 46-72, 2007.

Cai, W. J. and Reimers, C. E.: Benthic oxygen flux, bottom water oxygen concentration and core top organic carbon content in the deep northeast Pacific Ocean, Deep-Sea Res. Pt. I, 42, 16811699, 1995.

Canfield, D. E., Jorgensen, B. B., Fossing, H., Glud, R., Gundersen, J., Ramsing, N. B., Thamdrup, B., Hansen, J. W., Nielsen, L. P., and Hall, P. O. J.: Pathways of organic-carbon oxidation in 3 continental margin sediments, Mar. Geol., 113, 27-40, 1993.

Canfield, D. E.: Factors Influencing organic carbon preservation in marine sediments, Chem. Geol., 114, 315-239, 1994.

Canfield, D. E.: Sulphate reduction and oxic respiration in marine sediments - Implications for organic carbon preservation in euxinic environments, Deep-Sea Res. Pt. I, 36, 121-138, 1989.

Childress, J. J. and Seibel, B. A.: Life at stable low oxygen levels: adaptations of animals to oceanic oxygen minimum layers, J. Exp. Biol., 201, 1223-1232, 1998.

Childs, C. R., Rabalais, N. N., Turner, R. E., and Proctor, L. M.: Sediment denitrification in the Gulf of Mexico zone of hypoxia, Mar. Ecol.-Prog. Ser., 240, 285-290, 2002.

Cloern, J. E.: Our evolving conceptual model of the coastal eutrophication problem, Mar. Ecol.-Prog. Ser., 210, 223-253, 2001.

Conley, D. J., Carstensen, J., Aertebjerg, G., Christensen, P. B., Dalsgaard, T., Hansen, J. L. S., and Josefson, A. B.: Long-term changes and impacts of hypoxia in Danish coastal waters, Ecol. Appl., 17, 165-184, 2007.

Conley, D. J., Humborg, C., Rahm, L., Savchuk, O. P., and Wulff, F.: Hypoxia in the Baltic Sea and basin-scale changes in phosphorus biogeochemistry, Environ. Sci. Technol., 36, 5315-5320, 2002.

Conley, D. J., Bjorck, S., Bonsdorff, E., Carstensen, J., Destouni, G., Gustafsson, B. G., Hietanen, S., Kortekaas, M., Kuosa, H., Meier, H. E. M., Muller-Karulis, B., Nordberg, K., Norkko, A., Nurnberg, G., Pitkanen, H., Rabalais, N. N., Rosenberg, R., Savchuk, O. P., Slomp, C. P., Voss, M., Wulff, F., and Zillen, L.: Hypoxia-related processes in the Baltic Sea, Environ. Sci. Technol., 43, 3412-3420, 2009.

Cowan, J. L. W. and Boynton, W. R.: Sediment-water oxygen and nutrient exchanges along the longitudinal axis of Chesa- 
peake Bay: Seasonal patterns, controlling factors and ecological significance, Estuaries, 19, 562-580, 1996.

Cowie, G.: The biogeochemistry of Arabian Sea surficial sediments: A review of recent studies, Prog. Oceanogr., 65, 260-289, 2005.

Cowie, G. L., Mowbray, S., Lewis, M., Matheson, H., and McKenzie, R.: Carbon and nitrogen elemental and stable isotopic compositions of surficial sediments from the Pakistan margin of the Arabian Sea, Deep-Sea Res. Pt. II, 56, 271-282, 2009.

Cowie, G. L., Hedges, J. I., and Calvert, S. E.: Sources and relative reactivities of amino acids, neutral sugars, and lignin in an intermittent anoxic marine environment, Geochim. Cosmochim. Ac., 56, 1963-1978, 1992.

Damsté, J. S. S. and de Leeuw, J. W.: Analysis, structure and geochemical significance of organically-bound sulphur in the geosphere: state of the art and future research, Org. Geochem., 16, 1077-1101, 1990.

Damsté, J. S. S., Rijpstra, W. I. C., and Reichart, G. J.: The influence of oxic degradation on the sedimentary biomarker record II, Evidence from Arabian Sea sediments, Geochim. Cosmochim. Ac., 66, 2737-2754, 2002.

Damsté, J. S. S., Wakeham, S. G., Kohnen, M. E. L., Hayes, J. M., and Deleeuw, J. W.: A 6000-Year sedimentary molecular record of chemocline excursions in the Black Sea, Nature, 362, 827829, 1993.

Dauer, D. M., Rodi, A. J., and Ranasinghe, J. A.: Effects of low dissolved oxygen events on the macrobenthos of the Lower Chesapeake Bay, Estuaries, 15, 384-391, 1992.

Dauwe, B., Middelburg, J. J., and Herman, P. M. J.: Effect of oxygen on the degradability of organic matter in subtidal and intertidal sediments of the North Sea area, Mar. Ecol.-Prog. Ser., 215, 13-22, 2001.

Dauwe, B., Middelburg, J. J., Herman, P. M. J., and Heip, C. H. R.: Linking diagenetic alteration of amino acids and bulk organic matter reactivity, Limnol. Oceanogr., 44, 1809-1814, 1999.

Demaison, G. J. and Moore, G. T.: Anoxic environments and oil source bed genesis, AAPG Bull.-Am. Assoc. Petr. Geol., 64, 1179-1209, 1980.

Diaz, R.: Overview of hypoxia around the world, J. Environ. Qual. 30, 275-281, 2001.

Diaz, R. J. and Rosenberg, R.: Marine benthic hypoxia: A review of its ecological effects and the behavioural responses of benthic macrofauna, London, Ann. Rev. Ocean. Mar. Biol., 33, 245-303, 1995.

Diaz, R. J. and Rosenberg, R.: Spreading dead zones and consequences for marine ecosystems, Science, 321, 926-929, 2008.

Duarte, C. M.: Submerged Aquatic Vegetation in Relation to Different Nutrient Regimes, Ophelia, 41, 87-112, 1995.

Eldridge, P. M. and Morse, J. W.: Origins and temporal scales of hypoxia on the Louisiana shelf: Importance of benthic and subpycnocline water metabolism, Mar. Chem., 108, 159-171, 2008

Emmerson, M. C., Solan, M., Emes, C., Paterson, D. M., and Raffaelli, D.: Consistent patterns and the idiosyncratic effects of biodiversity in marine ecosystems, Nature, 411, 73-77, 2001.

Ferdelman, T. G., Church, T. M., and Luther, G. W.: Sulfur enrichment of humic-substances in a Delaware saltmarsh sediment core, Geochim. Cosmochim. Ac., 55, 979-988, 1991.

Ferro, I., Van Nugteren, P., Middelburg, J. J., Herman, P. M. J., and Heip, C. H. R.: Effect of macrofauna, oxygen ex- change and particle reworking on iron and manganese sediment biogeochemistry: A laboratory experiment, Vie Milieu, 53, 211220, 2003.

Friedl, G., Dinkel, C., and Wehrli, B.: Benthic fluxes of nutrients in the northwestern Black Sea, Mar. Chem., 62, 77-88, 1998.

Forster, S., Graf, G., Kitlar, J., and Powilleit, M.: Effects of bioturbation in oxic and hypoxic conditions - a microcosm experiment with a North Sea sediment community, Mar. Ecol.-Prog. Ser., 116, 153-161, 1995.

Glazer, B. T., Luther, G. W., Konovalov, S. K., Friederich, G. E., Trouwborst, R. E., and Romanov, A. S.: Spatial and temporal variability of the Black Sea suboxic zone, Deep-Sea Res. Pt. II, 53, 1756-1768, 2006.

Glud, R. N.: Oxygen dynamics of marine sediments, Mar. Biol. Res., 4, 243-289, 2008.

Gooday, A. J., Jorissen, F., Levin, L. A., Middelburg, J. J., Naqvi, S. W. A., Rabalais, N. N., Scranton, M., and Zhang, J.: Historical records of coastal eutrophication-induced hypoxia, Biogeosciences Discuss., 6, 2567-2658, 2009,

http://www.biogeosciences-discuss.net/6/2567/2009/.

Grantham, B. A., Chan, F., Nielsen, K. J., Fox, D. S., Barth, J. A., Huyer, A., Lubchenco, J., and Menge, B. A.: Upwelling-driven nearshore hypoxia signals ecosystem and oceanographic changes in the northeast Pacific, Nature, 429, 749-754, 2004.

Gray, J. S., Wu, R. S. S., and Or, Y. Y.: Effects of hypoxia and organic enrichment on the coastal marine environment, Mar. Ecol.Prog. Ser., 238, 249-279, 2002.

Gutierrez, D., Gallardo, V. A., Mayor, S., Neira, C., Vasquez, C., Sellanes, J., Rivas, M., Soto, A., Carrasco, F., and Baltazar, M.: Effects of dissolved oxygen and fresh organic matter on the bioturbation potential of macrofauna in sublittoral sediments off Central Chile during the 1997/1998 El Nino, Mar. Ecol.-Prog. Ser., 202, 81-99, 2000.

Gutierrez, D., Enriquez, E., Purca, S., Quipuzcoa, L., Marquina, R., Flores, G., and Graco, M.: Oxygenation episodes on the continental shelf of central Peru: Remote forcing and benthic ecosystem response, Prog. Oceanogr., 79, 177-189, 2008.

Hargrave, B. T., Holmer, M., and Newcombe, C. P.: Towards a classification of organic enrichment in marine sediments based on biogeochemical indicators, Mar. Pollut. Bull., 56, 810-824, 2008.

Hartnett, H. E. and Devol, A. H.: Role of a strong oxygen-deficient zone in the preservation and degradation of organic matter: A carbon budget for the continental margins of northwest Mexico and Washington State, Geochim. Cosmochim. Ac., 67, 247-264, 2003.

Hartnett, H. E., Keil, R. G., Hedges, J. I., and Devol, A. H.: Influence of oxygen exposure time on organic carbon preservation in continental margin sediments, Nature, 391, 572-574, 1998.

Hedges, J. I. and Keil, R. G.: Organic geochemical perspectives on estuarine processes: sorption reactions and consequences, Mar. Chem., 65, 55-65, 1999.

Hedges, J. I. and Keil, R. G.: Sedimentary Organic-Matter Preservation - an Assessment and Speculative Synthesis, Mar. Chem., 49, 81-115, 1995.

Heip, C. H. R., Goosen, N. K., Herman, P. M. J., Kromkamp, J., Middelburg, J. J., and Soetaert, K.: Production and consumption of biological particles in temperate tidal estuaries, London, Ann. Rev. Ocean. Mar. Biol., 33, 1-150, 1995. 
Herman, P. M. J., Middelburg, J. J., Van de Koppel, J., and Heip, C. H. R.: Ecology of estuarine macrobenthos, Adv. Ecol. Res., 29, 195-240, 1999.

Hietanen, S. and Lukkari, K: The effect of short-term anoxia on benthic denitrification, nutrient fluxes, and phosphorus forms in the sediment, Aquat. Microb. Ecol. 49, 293-302, 2007.

Hoefs, M. J. L., Rijpstra, W. I. C., and Damste, J. S. S.: The influence of oxic degradation on the sedimentary biomarker record I: Evidence from Madeira Abyssal Plain turbidites, Geochim. Cosmochim. Ac., 66, 2719-2735, 2002.

Hulthe, G., Hulth, S., and Hall, P. O. J.: Effect of oxygen on degradation rate of refractory and labile organic matter in continental margin sediments, Geochim. Cosmochim. Ac., 62, 1319-1328, 1998.

Ieno, E. N., Solan, M., Batty, P., and Pierce, G. J.: How biodiversity affects ecosystem functioning: roles of infaunal species richness, identity and density in the marine benthos, Mar. Ecol.-Prog. Ser., 311, 263-271, 2006.

Ingall, E. and Jahnke, R.: Influence of water-column anoxia on the elemental fractionation of carbon and phosphorus during sediment diagenesis, Mar. Geol., 139, 219-229, 1997.

Jeppesen, E., Sondergaard, M., Jensen, J. P., Havens, K. E., Anneville, O., Carvalho, L., Coveney, M. F., Deneke, R., Dokulil, M. T., Foy, B., Gerdeaux, D., Hampton, S. E., Hilt, S., Kangur, K., Kohler, J., Lammens, E., Lauridsen, T. L., Manca, M., Miracle, M. R., Moss, B., Noges, P., Persson, G., Phillips, G., Portielje, R., Schelske, C. L., Straile, D., Tatrai, I., Willen, E., and Winder, M.: Lake responses to reduced nutrient loading - an analysis of contemporary long-term data from 35 case studies, Freshwat. Biol., 50, 1747-1771, 2005.

Jordan, T. E., Cornwell, J. C., Boynton, W. R., and Anderson, J. T.: Changes in phosphorus biogeochemistry along an estuarine salinity gradient: The iron conveyer belt, Limnol. Oceanogr., 53, 172-184, 2008.

Jørgensen, B. B.: Mineralization of organic matter in the sea bed the role of sulphate reduction, Nature, 296, 643-645, 1982.

Jørgensen, B. B.: Sulphur cycle of a coastal marine sediment (Limfjorden, Denmark), Limnol. Oceanogr., 22, 814-832, 1977.

Jørgensen, B. B.: Bacteria and marine biogeochemistry, edited by: Shulz, H. D. and Zabel, M., Mar. Geochem., 169-206, 2006.

Jørgensen, B. B. and Gallardo, V. A.: Thioploca spp.: filamentous sulphur bacteria with nitrate vacuoles, FEMS Microbial Ecol., 28, 301-313, 1999.

Katsev, S., Chaillou, G., Sundby, B., and Mucci, A.: Effects of progressive oxygen depletion on sediment diagenesis and fluxes: A model for the lower St. Lawrence River Estuary, Limnol. Oceanogr., 52, 2555-2568, 2007.

Kemp, W. M., Sampou, P., Caffrey, J., Mayer, M., Henriksen, K., and Boynton, W. R.: Ammonium recycling versus denitrification in chesapeake bay sediments, Limnol. Oceanogr., 35, 1545$1563,1990$.

Kemp, W. M., Boynton, W. R., Adolf, J. E., Boesch, D. F., Boicourt, W. C., Brush, G., Cornwell, J. C., Fisher, T. R., Glibert, P. M., Hagy, J. D., Harding, L. W., Houde, E. D., Kimmel, D. G., Miller, W. D., Newell, R. I. E., Roman, M. R., Smith, E. M., and Stevenson, J. C.: Eutrophication of Chesapeake Bay: historical trends and ecological interactions, Mar. Ecol.-Prog. Ser., 303, 1-29, 2005.

Kemp, W. M., Testa, J., Conley, D., Gilbert, D., and Hagy, J.:
Coastal hypoxia responses to remediation, accepted, in process of publication, Biogeos. Disc., 2009.

Konovalov, S. K., Luther, G. W., Friederich, G. E., Nuzzio, D. B. Tebo, B. M., Murray, J. W., Oguz, T., Glazer, B., Trouwborst, R. E., Clement, B., Murray, K. J., and Romanov, A. S.: Lateral injection of oxygen with the Bosporus plume - fingers of oxidizing potential in the Black Sea, Limnol. Oceanogr., 48, 2369-2376, 2003

Konovalov, S. K., Luther, G. W., and Yucel, M.: Porewater redox species and processes in the Black Sea sediments, Chem. Geol., 245, 254-274, 2007.

Kristensen, E., Ahmed, S. I., and Devol, A. H.: Aerobic and anaerobic decomposition of organic matter in marine sediment: Which is fastest?, Limnol. Oceanogr., 40, 1430-1437, 1995.

Kristensen, E., Kristiansen, K. D., and Jensen, M. H.: Temporal behavior of manganese and iron in a sandy coastal sediment exposed to water column anoxia, Estuaries, 26, 690-699, 2003.

Kristiansen, K. D., Kristensen, E., and Jensen, M. H.: The influence of water column hypoxia on the behaviour of manganese and iron in sandy coastal marine sediment, Estuar. Coast. Shelf S., 55, 645-654, 2002.

Lam, P., Jensen, M. M., Lavik, G., McGinnis, D. F., Muller, B., Schubert, C. J., Amann, R., Thamdrup, B., and Kuypers, M. M. M.: Linking crenarchaeal and bacterial nitrification to anammox in the Black Sea, P. Natl. Acad. Sci. USA, 104, 7104-7109, 2007.

Lamont, P. A. and Gage, J. D.: Morphological responses of macrobenthic polychaetes to low oxygen on the Oman continental slope, NW Arabian Sea, Deep-Sea Res. Pt. II, 47, 9-24, 2000.

Larson, F. and Sundback, K.: Role of microphytobenthos in recovery of functions in a shallow-water sediment system after hypoxic events, Mar. Ecol.-Prog. Ser., 357, 1-16, 2008.

Lavik, G., Stuhrmann, T., Brüchert, V., Van der Plas, A., Mohrholz, V., Lam, P., Mussmann, M., Fuchs, B. M., Amann, R., Lass, U., and Kuypers, M. M. M.: Detoxification of sulphidic African shelf waters by blooming chemolithotrophs, Nature, 457, 581586, 2009.

Lee, C.: Controls on organic carbon preservation - the use of stratified water bodies to compare intrinsic rates of decomposition in oxic and anoxic systems, Geochim. Cosmochim. Ac., 56, 33233335, 1992.

Levin, L., Blair, N., DeMaster, D., Plaia, G., Fornes, W., Martin, C., and Thomas, C.: Rapid subduction of organic matter by maldanid polychaetes on the North Carolina slope, J. Mar. Res., 55, 595-611, 1997.

Levin, L. A., Gage, J. D., Martin, C., and Lamont, P. A.: Macrobenthic community structure within and beneath the oxygen minimum zone, NW Arabian Sea, Deep-Sea Res. Pt. II, 47, 189226, 2000.

Levin, L. A.: Oxygen minimum zone benthos: Adaptation and community response to hypoxia, Ann. Rev. Oceanogr. Mar. Biol., 41, $1-45,2003$.

Levin, L. A., Ekau, W., Gooday, A. J., Jorissen, F., Middelburg, J. J., Naqvi, W., Neira, C., Rabalais, N. N., and Zhang, J.: Effects of natural and human-induced hypoxia on coastal benthos, Biogeosciences Discuss., 6, 3563-3654, 2009, http://www.biogeosciences-discuss.net/6/3563/2009/.

Levin, L. A., Whitcraft, C., Mendoza, G. F., Gonzalez, J., and Cowie, G.: Oxygen and organic matter thresholds for benthic faunal activity on the Pakistan margin oxygen minimum zone 
(700-1100 m), Deep-Sea Res. Pt. II., 56, 449-471, 2009 b.

Lewis, B. L., Glazer, B. T., Montbriand, P. J., Luther, G. W., Nuzzio, D. B., Deering, T., Ma, S., and Theberge, S.: Short-term and interannual variability of redox-sensitive chemical parameters in hypoxic/anoxic bottom waters of the Chesapeake Bay, Mar. Chem., 105, 296-308, 2007.

Luther, G. W., Ma, S. F., Trouwborst, R., Glazer, B., Blickley, M., Scarborough, R. W., and Mensinger, M. G.: The roles of anoxia, $\mathrm{H}_{2} \mathrm{~S}$, and storm events in fish kills of dead-end canals of Delaware inland bays, Estuaries, 27, 551-560, 2004.

Lyons, T. W., Berner, R. A., and Anderson, R. F.: Evidence for large preindustrial perturbations of the Black Sea chemocline, Nature, 365, 538-540, 1993.

Ma, S. F., Whereat, E. B., and Luther, G. W.: Shift of algal community structure in dead end lagoons of the Delaware Inland Bays during seasonal anoxia, Aquat. Microb. Ecol., 44, 279-290, 2006.

Marinelli, R. L. and Williams, T. J.: Evidence for density-dependent effects of infauna on sediment biogeochemistry and benthicpelagic coupling in nearshore systems, Estuar. Coast. Shelf S., 57, 179-192, 2003.

Marinelli, R. L. and Woodin, S. A.: Experimental evidence for linkages between infaunal recruitment, disturbance, and sediment surface chemistry, Limnol. Oceanogr., 47, 221-229, 2002.

Mayer, L. M.: Surface area control of organic carbon accumulation in continental shelf sediments, Geochim. Cosmochim. Ac., 58, 1271-1284, 1994.

McCarthy, M. J., McNeal, K. S., Morse, J. W., and Gardner, W. S.: Bottom-water hypoxia effects on sediment-water interface nitrogen transformations in a seasonally hypoxic, shallow bay (Corpus christi bay, TX, USA), Estuar. Coasts, 31, 521-531, 2008.

Mee, D., Friedrich, J., and Gomoiu, M.: Restoring the Black Sea in times of uncertainty, Oceanography, 18, 100-112, 2005.

Mermillod-Blondin, F., Francois-Carcaillet, F., and Rosenberg, R.: Biodiversity of benthic invertebrates and organic matter processing in shallow marine sediments: an experimental study, J. Exp. Mar. Biol. Ecol., 315, 187-209, 2005.

Meysman, F. J. R., Boudreau, B. P., and Middelburg, J. J.: Relations between local, nonlocal, discrete and continuous models of bioturbation, J. Mar. Res., 61, 391-410, 2003.

Meysman, F. J. R., Boudreau, B. P., and Middelburg, J. J.: Modeling reactive transport in sediments subject to bioturbation and compaction, Geochim. Cosmochim. Ac., 69, 3601-3617, 2005.

Meysman, F. J. R., Middelburg, J. J., and Heip, C. H. R.: Bioturbation: a fresh look at Darwin's last idea, Trends Ecol. Evol., 21, 688-695, 2006.

Meysman, F. J. R., Malyuga, V. S., Boudreau, B. P., and Middelburg, J. J.: A generalized stochastic approach to particle dispersal in soils and sediments, Geochim. Cosmochim. Ac., 72, 34603478, 2008.

Meysman, F. J. R. and Middelburg, J. J.: Acid-volatile sulphide (AVS) - A comment, Mar. Chem., 97, 206-212, 2005.

Middelburg, J. J.: Organic carbon, sulphur, and iron in recent semieuxinic sediments of Kau Bay, Indonesia, Geochim. Cosmochim. Ac., 55, 815-828, 1991.

Middelburg, J. J. and Meysman, F. J. R.: Ocean science - Burial at sea, Science, 316, 1294-1295, 2007.

Middelburg, J. J., Calvert, S. E., and Karlin, R.: Organic-rich transitional facies in silled basins - Response to sea-level change,
Geology, 19, 679-682, 1991.

Middelburg, J. J., Vlug, T., and Van der Nat, F.: Organic matter mineralization in marine systems, Global Planet. Change, 8, 4758, 1993.

Middelburg, J. J., Soetaert, K., Herman, P. M. J., and Heip, C. H. R.: Denitrification in marine sediments: A model study, Global Biogeochem. Cy., 10, 661-673, 1996.

Monteiro, P. M. S., van der Plas, A., Mohrholz, V., Mabille, E., Pascall, A., and Joubert, W.: Variability of natural hypoxia and methane in a coastal upwelling system: Oceanic physics or shelf biology?, Geophys. Res. Lett., 33, L16614, doi:10.129/2006GL026234, 2006.

Monteiro, P. M. S., van der Plas, A. K., Melice, J. L., and Florenchie, P.: Interannual hypoxia variability in a coastal upwelling system: Ocean-shelf exchange, climate and ecosystem-state implications, Deep-Sea Res. Pt. I, 55, 435-450, 2008.

Montserrat, F., Van Colen, C., Degraer, S., Ysebaert, T., and Herman, P. M. J.: Benthic community-mediated sediment dynamics, Mar. Ecol.-Prog. Ser., 372, 43-59, 2008.

Moodley, L., Middelburg, J. J., Herman, P. M. J., Soetaert, K., and de Lange, G. J.: Oxygenation and organic-matter preservation in marine sediments: Direct experimental evidence from ancient organic carbon-rich deposits, Geology, 33, 889-892, 2005.

Morales, C. E., Hormazabal, S. E., and Blanco, J. L.: Interannual variability in the mesoscale distribution of the depth of the upper boundary of the oxygen minimum layer off northern Chile (1824S): Implications for the pelagic system and biogeochemical cycling, J. Mar. Res., 57, 909-932, 1999.

Morse, J. W. and Eldridge, P. M.: A non-steady state diagenetic model for changes in sediment biogeochemistry in response to seasonally hypoxic/anoxic conditions in the "dead zone" of the Louisiana shelf, Mar. Chem., 106, 239-255, 2007.

Mortimer, C. H.: The exchange of dissolved substances between mud and water in lakes, Part I and II, J. Ecol., 29, 280-329, 1941.

Mountford, N. K., Holland, A. F., and Mihursky, J. A.: Identification and Description of Macrobenthic Communities in Calvert Cliffs Region of Chesapeake Bay, Chesapeake Science, 18, 360369, 1977.

Naqvi, S. W. A., Jayakumar, D. A., Narvekar, P. V., Naik, H., Sarma, V. V. S. S., D'Souza, W., Joseph, T., and George, M. D.: Increased marine production of $\mathrm{N}_{2} \mathrm{O}$ due to intensifying anoxia on the Indian continental shelf, Nature, 408, 346-349, 2000.

Naqvi, S. W. A., Naik, H., Pratihary, A., D’Souza, W., Narvekar, P. V., Jayakumar, D. A., Devol, A. H., Yoshinari, T., and Saino, T.: Coastal versus open-ocean denitrification in the Arabian Sea, Biogeosciences, 3, 621-633, 2006, http://www.biogeosciences.net/3/621/2006/.

Naqvi, S. W. A., Bange, H., Farias, L., Monteiro, P. M. S, and Zhang, J.: Coastal hypoxia/anoxia as a source of $\mathrm{CH}_{4}$ and $\mathrm{N}_{2} \mathrm{O}$, Biogeosci. Discuss., in preparation, 2009.

Neira, C., Sellanes, J., Soto, A., Gutierrez, D., and Gallardo, V. A.: Meiofauna and sedimentary organic matter off Central Chile: response to changes caused by the 1997-1998 El Nino, Oceanol. Acta, 24, 313-328, 2001.

Nilsson, H. C. and Rosenberg, R.: Succession in marine benthic habitats and fauna in response to oxygen deficiency: analysed by sediment profile-imaging and by grab samples, Mar. Ecol.-Prog. Ser., 197, 139-149, 2000.

Norkko, A., Rosenberg, R., Thrush, S. F., and Whitlatch, R. B.: 
Scale- and intensity-dependent disturbance determines the magnitude of opportunistic response, J. Exp. Mar. Biol. Ecol., 330, 195-207, 2006.

Norling, P. and Kautsky, N.: Structural and functional effects of Mytilus edulis on diversity of associated species and ecosystem functioning, Mar. Ecol.-Prog. Ser., 351, 163-175, 2007.

Officer, C. B., Biggs, R. B., Taft, J. L., Cronin, L. E., Tyler, M. A., and Boynton, W. R.: Chesapeake Bay Anoxia - Origin, Development, and Significance, Science, 223, 22-27, 1984.

Olenin, S.: Benthic zonation of the eastern Gotland Basin, Baltic Sea. Neth., J. Aquat. Ecol., 30, 265-282, 1997.

Overmann, J., Cypionka, H., and Pfennig, N.: An extremely lowlight adapted phototrophic sulphur bacterium from the Black Sea, Limnol. Oceanogr., 37, 150-155, 1992.

Pakhornova, S. V., Hall, P. O. J., Kononets, M. Y., Rozanov, A. G., Tengberg, A., and Vershinin, A. V.: Fluxes of iron and manganese across the sediment-water interface under various redox conditions, Mar. Chem., 107, 319-331, 2007.

Passier, H. F., Middelburg, J. J., de Lange, G. J., and Bottcher, M. E.: Pyrite contents, microtextures, and sulphur isotopes in relation to formation of the youngest eastern Mediterranean sapropel, Geology, 25, 519-522, 1997.

Pearson, T. H. and Rosenberg, R.: Macrobenthic succession in relation to organic enrichment and pollution of the marine environment, Ann. Rev. Oceanogr. Mar. Biol., 16, 229-311, 1978.

Pedersen, T. F. and Calvert, S. E.: Anoxia vs productivity - What controls the formation of organic-carbon-rich sediments and sedimentary rocks, AAPG Bull.-Am. Assoc. Petr. Geol., 74, 454466, 1990

Percy, D., Li, X. N., Taylor, G. T., Astor, Y., and Scranton, M. I.: Controls on iron, manganese and intermediate oxidation state sulphur compounds in the Cariaco Basin, Mar. Chem., 111, 4762, 2008.

Pihl, L., Baden, S. P., Diaz, R. J. and Schaffner, L. C.: Hypoxia induced structural changes in the diets of bottom-feeding fish and crustacea, Mar. Biol., 112, 349-362, 1992.

Quiroga, E., Quinones, R., Palma, M., Sellanes, J., Gallardo, V. A., Gerdes, D., and Rowe, G.: Biomass size-spectra of macrobenthic communities in the oxygen minimum zone off Chile, Estuar. Coast. Shelf S., 62, 217-231, 2005.

Rabalais, N. N., Atilla, N., Normandeau, C., and Turner, R. E.: Ecosystem history of Mississippi River-influenced continental shelf revealed through preserved phytoplankton pigments, Mar. Pollut. Bull., 49, 537-547, 2004.

Rabalais, N. N., Harper Jr., D. E., and Turner, R. E.: Responses of nekton and demersal and benthic fauna to decreasing oxygen concentrations, in: Coastal and Estuarine Studies: Coastal Hypoxia Consequences for Living Resources and Ecosystems, edited by: Rabalais, N. N. and Turner, R. E., American Geophysical Union, Washington, D. C., 115-128, 2001a.

Rabalais, N. N., Smith, L. E., Harper Jr., D. E. and Dubravko, J.: Effects of Seasonal Hypoxia on Continental Shelf Benthos, in: Coastal and Estuarine Studies: Coastal Hypoxia Consequences for Living Resources and Ecosystems, edited by: Rabalais, N. N. and Turner, R. E., American Geophysical Union, Washington, D. C., 211-240, 2001b.

Raghoebarsing A. A., Pol, A., van de Pas-Schoonen, K. T., Smolders, A. J. P., Ettwig, K. F., Rijpstra, W. I. C., Schouten, S., Sinninghe Damsté, J. S., Op den Camp, H. J. M., Jetten, M.
S. M., and Strous, M.: A microbial consortium couples anaerobic methane oxidation to denitrification, Nature, 440, 918-921, 2006.

Reimers, C. E. and Suess, E.: The partitioning of organic-carbon fluxes and sedimentary organic matter decomposition rates in the ocean, Mar. Chem., 13, 141-168, 1983.

Reise, K.: Tidal Flat Ecology: An experimental approach to species interactions, Ecological Studies 54, Springer-Verlag, Berlin, 191 pp., 1985.

Rhoads, D. C. and Boyer, L. F.: The effects of marine benthos on physical properties of sediments: a successional perspective, In: Animal-sediment relations, edited by: McCall, P. L. and Tevesz, M. J. S., Plenum Press, New York, pp.3-52, 1982.

Rhoads, D. C. and Morse, J. W.: Evolutionary and ecological significance of oxygen-deficient marine basins, Lethaia, 4, 413-428, 1971.

Rhoads D. C.: Organism sediment relations on the muddy sea floor, Ann. Rev. Ocean. Mar. Biol., 12, 263-300, 1974.

Ritter, C. and Montagna, P. A.: Seasonal hypoxia and models of benthic response in a Texas bay, Estuaries, 22, 7-20, 1999.

Rosenberg, R., Hellman, B., and Johansson, B.: Hypoxic tolerance of marine benthic fauna, Mar. Ecol.-Prog. Ser., 79, 127-131, 1991.

Rosenberg, R., Agrenius, S., Hellman, B., Nilsson, H. C., and Norling, K.: Recovery of marine benthic habitats and fauna in a Swedish fjord following improved oxygen conditions, Mar. Ecol.-Prog. Ser., 234, 43-53, 2002.

Rossi, F., Gribsholt, B., Middelburg, J. J., and Heip, C.: Contextdependent effects of suspension feeding on intertidal ecosystem functioning, Mar. Ecol.-Prog. Ser., 354, 47-57, 2008.

Rossi, F., Vos, M., Middelburg, J. J.: Species identity, diversity and microbial carbon flow in reassembling macrobenthic communities, Oikos, 118, 503-512, 2009.

Rozan, T. F., Taillefert, M., Trouwborst, R. E., Glazer, B. T., Ma, S. F., Herszage, J., Valdes, L. M., Price, K. S., and Luther, G. W.: Iron-sulphur-phosphorus cycling in the sediments of a shallow coastal bay: Implications for sediment nutrient release and benthic macroalgal blooms, Limnol. Oceanogr., 47, 1346-1354, 2002.

Rowe, G. T., Kaegi, M. E. C., Morse, J. W., Boland, G. S., and Briones, E. G. E.: Sediment community metabolism associated with continental shelf hypoxia, Northern Gulf of Mexico, Estuaries, 25, 1097-1106, 2002.

Rowe, G. T., Morse, J., Nunnally, C., and Boland, G. S.: Sediment community oxygen consumption in the deep Gulf of Mexico, Deep-Sea Res. Pt. II, 55, 2686-2691, 2008.

Savrda, C. E. and Bottjer, D. J.: The exaerobic zone, a new oxygen deficient marine biofacies, Nature, 327, 54-56, 1987.

Savrda, C. E. and Bottjer, D. J.: Oxygen-related biofacies in marine strata: an overview and update, in: Modern and ancient continental shelf anoxia, edited by: Tyson, R. V. and Pearson, T. H., Geol. Soc. Spec. Publ., 58, 201-219, 1991

Savrda, C. E., Bottjer, D. J., and Gorsline, D. S.: Development of a comprehensive oxygen-deficient marine biofacies model; evidence from Santa Monica, San Pedro, and Santa Barbara basins, California continental borderland, AAPG Bull., 58, 1179-1192, 1984.

Schaffner L. C., Jonsson P., Diaz R. J., Rosenberg R., and Gapcynski P.: Benthic communities and bioturbation history of estuar- 
ine and coastal systems: effects of hypoxia and anoxia, Sci. Total Environ. (supplement), 1001-1017, 1992.

Schulz, H. N. and Jorgensen, B. B.: Big bacteria, Annu. Rev. Microbiol., 55, 105-137, 2001.

Schulz, H. N. and Schulz, H. D.: Large sulphur bacteria and the formation of phosphorite, Science, 307, 416-418, 2005.

Sellanes, J. and Neira, C.: ENSO as a natural experiment to understand environmental control of meiofaunal community structure, Mar. Ecol.-Evol. Persp., 27, 31-43, 2006.

Sellanes, J., Neira, C., and Quiroga, E.: Composition, structure and energy flux of the meiobenthos off central Chile, Rev. Chil. Hist. Nat., 76, 401-415, 2003.

Sellanes, J., Quiroga, E., Neira, C., and Gutierrez, D.: Changes of macrobenthos composition under different ENSO cycle conditions on the continental shelf off central Chile, Cont. Shelf Res., 27, 1002-1016, 2007.

Severmann, S., Lyons, T. W., Anbar, A., McManus, J., and Gordon, G.: Modern iron isotope perspective on the benthic iron shuttle and the redox evolution of ancient oceans, Geology, 36, 487-490, 2008.

Shaffer, G.: Phosphate Pumps and Shuttles in the Black-Sea, Nature, 321, 515-517, 1986.

Sholkovitz, E. R. and Gieskes J. M.: A physical chemical study of the flushing of the Santa Barbara Basin, Limnol. Oceanogr., 16, 479-489, 1971.

Slomp, C. P., Epping, E. H. G., Helder, W., and Van Raaphorst, W.: A key role for iron-bound phosphorus in authigenic apatite formation in North Atlantic continental platform sediments, J. Mar. Res., 54, 1179-1205, 1996.

Slomp, C. P. and Van Cappellen, P.: The global marine phosphorus cycle: sensitivity to oceanic circulation, Biogeosciences, 4 , 155171,2007 , http://www.biogeosciences.net/4/155/2007/.

Soetaert, K. and Middelburg, J. J.: Modeling eutrophication and oligotrophication of shallow-water marine systems: the importance of sediments under stratified and well mixed conditions, Hydrobiologia, 629, 239-254, 2009.

Soetaert, K., Herman, P. M. J., and Middelburg, J. J.: A model of early diagenetic processes from the shelf to abyssal depths, Geochim. Cosmochim. Ac., 60, 1019-1040, 1996.

Soetaert, K., Middelburg, J. J., Herman, P. M. J., and Buis, K.: On the coupling of benthic and pelagic biogeochemical models, Earth-Sci. Rev., 51, 173-201, 2000.

Strous, M. and Jetten, M. S. M.: Anaerobic oxidation of methane and ammonium, Annu. Rev. Microbiol., 58, 99-117, 2004.

Suess, E.: Mineral phases formed in anoxic sediments by microbial decomposition of organic matter, Geochim. Cosmochim. Ac., 43, 339-352, 1979.

Sundby, B., Gobeil, C., Silverberg, N., and Mucci, A.: The phosphorus cycle in coastal marine sediments, Limnol. Oceanogr., 37 , 1129-1145, 1992.

Sundby, B., Anderson, L. G., Hall, P. O. J., Iverfeldt, A., Vanderloeff, M. M. R., and Westerlund, S. F. G.: The effect of oxygen on release and uptake of cobalt, manganese, iron and phosphate at the sediment-water interface, Geochim. Cosmochim. Ac., 50, 1281-1288, 1986.

Sundby, B. and Silverberg, N.: Manganese fluxes in the benthic boundary layer, Limnol. Oceanogr., 30, 372-381, 1985.

Taylor, G. T., Labichella, M., Ho, T. Y., Scranton, M. I., Thunell, R.
C., Muller-Karger, F., and Varela, R.: Chemoautotrophy in the redox transition zone of the Cariaco Basin: A significant midwater source of organic carbon production, Limnol. Oceanogr., 46, 148-163, 2001.

Thamdrup, B.: Bacterial manganese and iron reduction in aquatic sediments, Adv. Microb. Ecol., 16, 41-84, 2000.

Thamdrup, B., Canfield D. E., Ferdelman T. G., Glud R. N., and Gundersen J. K.: A biogeochemical survey of the anoxic basin Golfo Dulce, Costa Rica, Rev. Biol. Trop., 44 Suppl., 3, 19-33, 1996.

Thamdrup, B., Fossing, H., and Jorgensen, B. B.: Manganese, iron, and sulphur cycling in a coastal marine sediment, Aarhus Bay, Denmark, Geochim. Cosmochim. Ac., 58, 5115-5129, 1994.

Thomson, J., Mercone, D., de Lange, G. J., and van Santvoort, P. J. M.: Review of recent advances in the interpretation of eastern Mediterranean sapropel $\mathrm{S}_{1}$ from geochemical evidence, Mar. Geol., 153, 77-89, 1999.

Toth, D. J. and Lerman, A.: Organic matter reactivity and sedimentation rates in ocean, Am. J. Sci., 277, 465-485, 1977.

Turner, R. E., Rabalais, N. N., and Justic, D.: Gulf of Mexico hypoxia: Alternate states and a legacy, Environ. Sci. Technol., 42, 2323-2327, 2008.

Tyson, R. V.: Sedimentary Organic matter, Chapman and Hall, 1995.

Vaquer-Sunyer, R. and Duarte, C. M.: Thresholds of hypoxia for marine biodiversity, P. Natl. Acad. Sci. USA, 105, 15452-15457, 2008.

Van Colen, C., Montserrat, F., Vincx, M., Herman, P. M. J., Ysebaert, T., and Degraer, S.: Macrobenthic recovery from hypoxia in an estuarine tidal mudflat, Mar. Ecol.-Prog. Ser., 372, 31-42, 2008.

Vandewiele, S., Cowie, G., Soetaert, K., and Middelburg, J. J.: Amino acid biogeochemistry and organic matter degradation state accross the Pakistan Margin Oxygen minimum zone, DeepSea Res. Pt. II, 56, 376-392, 2009.

van Nugteren, P., Herman, P. M. J., Moodley, L., Middelburg, J. J., Vos, M., and Heip C. H. R.: Spatial distribution of detrital resources determines the outcome of competition between bacteria and a facultative detritivorous worm, Limnol. Oceanogr., 54, 1413-1419, 2009.

Voss, M., Nausch, G., and Montoya, J. P.: Nitrogen stable isotope dynamics in the central Baltic Sea: influence of deep-water renewal on the N-cycle changes, Mar. Ecol.-Prog. Ser., 158, 11-21, 1997.

Waldbusser, G. G. and Marinelli, R. L.: Macrofaunal modification of porewater advection: role of species function, species interaction, and kinetics, Mar. Ecol.-Prog. Ser., 311, 217-231, 2006.

Waldbusser, G. G., Marinelli, R. L., Whitlatch, R. B., and Visscher, P. T.: The effects of infaunal biodiversity on biogeochemistry of coastal marine sediments, Limnol. Oceanogr., 49, 1482-1492, 2004.

Wallmann, K.: Feedbacks between oceanic redox states and marine productivity: A model perspective focused on benthic phosphorus cycling, Global Biogeochem. Cy., 17(3), 1084, doi:10.1029/2002GB001968.doi, 2003.

Werne, J. P., Lyons, T. W., Hollander, D. J., Schouten, S., Hopmans, E. C., and Damsté, J. S. S.: Investigating pathways of diagenetic organic matter sulfurization using compound-specific sulfur isotope analysis. Geochim. Cosmochim. Ac., 72, 3489-3502, 2008. 
Westrich, J. T. and Berner, R. A.: The role of sedimentary organic matter in bacterial sulphate reduction - the G model tested, Limnol. Oceanogr., 29, 236-249, 1984.

Wheatcroft, R. A.: Characteristic trace-fossil associations in oxygen-poor sedimentary environments - Comment, Geology, 17, p. 674, 1989.

Widdows, J., Blauw, A., Heip, C. H. R., Herman, P. M. J., Lucas, C. H., Middelburg, J. J., Schmidt, S., Brinsley, M. D., Twisk, F., and Verbeek, H.: Role of physical and biological processes in sediment dynamics (sedimentation, erosion and mixing) of a tidal flat in Westerschelde estuary, S.W. Netherlands, Mar. Ecol.Prog. Ser., 274, 41-56, 2004.

Wijsman, J. W. M., Middelburg, J. J., and Heip, C. H. R.: Reactive iron in Black Sea Sediments: implications for iron cycling, Mar. Geol., 172, 167-180, 2001.

Wilson, T. R. S., Thomson, J., Colley, S., Hydes, D. J., Higgs, N. C., and Sorensen, J.: Early Organic Diagenesis - the Significance of Progressive Subsurface Oxidation Fronts in Pelagic Sediments, Geochim. Cosmochim. Ac., 49, 811-822, 1985.

Woulds, C., Cowie, G. L., Levin, L. A., Andersson, J. H., Middelburg, J. J., Vandewiele, S., Lamont, P. A., Larkin, K. E., Gooday, A. J., Schumacher, S., Whitcraft, C., Jeffreys, R. M., and Schwartz, M.: Oxygen as a control on seafloor biological communities and their roles in sedimentary carbon cycling, Limnol. Oceanogr., 52, 1698-1709, 2007.
Woulds, C., Andersson, J. H., Cowie, G. L., Middelburg, J. J., and Levin, L. A.: ${ }^{13} \mathrm{C}$ tracer studies on the short-term fate of organic carbon in marine sediments: comparing the Pakistan margin to other regions, Deep-Sea Res. Pt. II, 56, 393-402, 2009.

Wüchter, C., Abbas, B., Coolen, M. J. L., Herfort, L., van Bleijswijk, J., Timmers, P., Strous, M., Teira, E., Herndl, G. J., Middelburg, J. J., Schouten, S., and Damsté, J. S. S.: Archaeal nitrification in the ocean, P. Natl. Acad. Sci. USA, 103, 12317-12322, 2006.

Yakushev, E. V., Pollehne, F., Jost, G., Kuznetso, I., Schneider, B., and Urnlauf, L.: Analysis of the water column oxic/anoxic interface in the Black and Baltic seas with a numerical model, Mar. Chem., 107, 388-410, 2007.

Zopfi, J., Ferdelman, T. G., Jorgensen, B. B., Teske, A., and Thamdrup, B.: Influence of water column dynamics on sulphide oxidation and other major biogeochemical processes in the chemocline of Mariager Fjord (Denmark), Mar. Chem., 74, 29-51, 2001. 